\title{
Functional Efficacy of Dystrophin Expression from Plasmids Delivered to $m d x$ Mice by Hydrodynamic Limb Vein Injection
}

\author{
Guofeng Zhang,, ${ }^{1,2}$ Christine I. Wooddell, ${ }^{3}$ Julia O. Hegge, Jacob B. Griffin, ${ }^{3}$ \\ Thierry Huss, ${ }^{4}$ Serge Braun, ${ }^{5}$ and Jon A. Wolff ${ }^{1,2}$
}

\begin{abstract}
In these studies we delivered by hydrodynamic limb vein (HLV) injection plasmid DNA (pDNA) expressing the full-length mouse dystrophin gene to skeletal muscles throughout the hind limbs of the $m d x$ mouse model for Duchenne muscular dystrophy (DMD). We evaluated the levels and stability of dystrophin expression and measured the resulting muscle protection, using Evans blue dye (EBD) to mark the damaged myofibers. Plasmid delivery was as efficient in the dystrophic mice as in wild-type mice and equally efficient in young adult and old mice, as long as the dose of pDNA was adjusted for the target muscle weight. The HLV gene delivery procedure was tolerated well by the dystrophic mice and repeat injections could be performed over an extended period of time. Multiple gene deliveries additively increased the amount of dystrophin protein and also increased the percentages of dystrophin-expressing myofibers. Plasmids expressing dystrophin from a cytomegalovirus (CMV) promoter construct containing the HMG1 intron provided stable dystrophin expression for the life of the mouse and provided significant benefit to the limbs. EBD staining showed that dystrophin gene delivery preserved myofibers in the CMV-HMGi-mDys-injected leg by 2.5- to 5-fold in large groups of muscles and by 2.5-fold throughout the injected legs, compared with the contralateral control legs injected with a nonexpressing plasmid. A similar degree of protection was measured in young adult mice evaluated soon after the last gene delivery and in aged mice injected over an extended period of time. This degree of protection resulted from 18 to $20 \%$ of the normal level of dystrophin protein, with 11-16\% dystrophin-expressing myofibers. These studies show promise for the use of HLV injections to deliver therapeutic doses of full-length dystrophin-expressing plasmids for long-lasting protection of skeletal muscles in patients with DMD.
\end{abstract}

\section{Introduction}

D UCHENNE MUSCULAR DYSTROPHY (DMD) is a severe X-linked neuromuscular disease afflicting 1 in every 3500 males and is due to a mutation in the dystrophin gene, causing myofiber necrosis and widespread muscle wasting. Boys with DMD lose the ability to walk by the age of 12 years and usually do not survive beyond early adulthood. The milder Becker form of muscular dystrophy arises from mutations in the dystrophin gene that retain some function. Twothirds of the cases of Duchenne or Becker muscular dystrophy are caused by large deletions of the dystrophin gene and most of the remaining one-third are caused by smaller deletions or point mutations that usually introduce a stop codon (Monaco et al., 1985; Koenig et al., 1987; Den Dunnen et al., 1989). At more than $400 \mathrm{kDa}$, the dystrophin protein is the largest member of the dystrophin-glycoprotein complex that spans the cell membrane and links the myofiber cytoskeleton with the basal lamina, thereby maintaining the integrity of the muscle fiber (Ervasti and Campbell, 1991; Matsumura et al., 1993; De la Porte et al., 1999; Blake et al., 2002). Rupture of the myofiber membrane allows calcium to enter and results in a cascade of events that lead to myofiber death and wasting of the muscle (Deconinck and Dan, 2007).

\footnotetext{
${ }^{1}$ Department of Pediatrics and Department of Medical Genetics, Waisman Center, University of Wisconsin-Madison, Madison, WI 53705.

${ }^{2}$ Present address: Roche Madison, Madison, WI 53711.

${ }^{3}$ Roche Madison, Madison, WI 53711.

${ }^{4}$ Transgene, Illkirch-Graffenstaden 67405, France.

${ }^{5}$ Association Française contre les Myopathies, Evry 91002, France.
} 
There are no cures for DMD at present in the clinic, but there has been a flowering of new approaches for treatment. The treatments can be broadly categorized as gene therapy, cell-based approaches, and drug therapies (Allamand and Campbell, 2000; Voisin and De la Porte, 2004; Cossu and Sampaolesi, 2007; Braun, 2008). Gene therapies involve nonviral delivery of the dystrophin gene in a plasmid or viral delivery of the internally deleted minidystrophin or a U1 or U7 small nuclear RNA expression vector to skip exons containing mutations (Goyenvalle et al., 2004; Romero et al., 2004; Zhang et al., 2004; Denti et al., 2006; Odom et al., 2007). Cell-based therapies involve myogenic precursor cells or stem cells (Sampaolesi et al., 2006; Kimura et al., 2008). Some drug therapies may be palliative to reduce muscle inflammation and degeneration (Matsumura et al., 2009). Others are designed to replace dystrophin by expression of an internally modified endogenous dystrophin gene via antisense oligonucleotides to induce exon skipping or read-through of nonsense mutations (Yokota et al., 2007) or by upregulating endogenous utrophin as a replacement for dystrophin (Miura and Jasmin, 2006). Each of these approaches has advantages and disadvantages.

Nonviral delivery of naked plasmid DNA (pDNA) to express therapeutic genes is an attractive approach to treat muscle diseases and has a good safety record (Braun, 2008; Duan, 2008). Plasmid DNA is a stable, biologically active molecule that is relatively inexpensive to produce in large quantities. Unlike viral vectors, pDNA does not induce an immune response toward the vector and thus repeat deliveries for chronic diseases are possible (Jiao et al., 1992; Le et al., 2000; Zhang et al., 2001; Hagstrom et al., 2004; Romero et al., 2004). The full-length dystrophin gene can be encoded in a plasmid and delivered to skeletal muscles (Acsadi et al., 1991; Danko et al., 1993; Hagstrom et al., 2004; Romero et al., 2004; Zhang et al., 2004). Plasmid DNA delivered to skeletal muscle of rodents or primates is retained in muscle fibers and expresses the encoded gene product for many months, likely because the differentiated skeletal myofibers have a low rate of turnover (Wolff et al., 1992; Danko et al., 1993, 1997; Zhang et al., 2004; Sebestyen et al., 2007). Such vectors have been delivered locally to skeletal muscles in mice by intramuscular injection and electroporation (Wolff et al., 1992; Danko et al., 1993, 1997; Hartikka et al., 2001). More recently, vascular delivery procedures have been used to deliver pDNA to an entire limb by intraarterial injection (Zhang et al., 2001, 2004) or by hydrodynamic limb vein (HLV) injection (Hagstrom et al., 2004). In the HLV injection procedure, a tourniquet is used to limit the delivery area to one limb per injection. Naked pDNA is rapidly injected into the vein in the anterograde direction. A sufficient volume of saline is used to facilitate extravasation of the pDNA from the vasculature and into the muscle tissue. The transcutaneous injection is a nonsurgical procedure in large animals, and multiple injections can be performed to increase expression levels. This procedure has a good safety profile (Hagstrom et al., 2004; Toumi et al., 2006; Vigen et al., 2007) and is a compelling candidate for the treatment of neuromuscular diseases such as DMD.

The $m d x$ mouse is the most widely used animal model for DMD (for reviews see Allamand and Campbell, 2000; Grounds et al., 2008). There are several strains of $m d x$ mice that all have a mutated dystrophin gene and the genetics are well defined. The $D m d^{m d x}$ strain $(m d x-10 \mathrm{ScSn})$ arose spontaneously from the C57BL/10ScSn strain. These mice have a premature termination codon in exon 23. Approximately $1 \%$ of the myofibers are revertants that express a truncated dystrophin protein. The $D m d^{m d x-4 C v}(m d x 4 \mathrm{Cv})$ strain was developed by chemical mutagenesis and backcrossed into the $\mathrm{C} 57 \mathrm{BL} / 6$ strain. $m d x 4 \mathrm{Cv}$ mice have a premature termination codon in exon 53 of the dystrophin gene. This strain has 10 times fewer revertant myofibers than the $m d x-10 S c S n$ strain (Danko et al., 1992). The DMD disease phenotype appears less severe in $m d x$ mice than in humans. Compensatory mechanisms that decrease the severity of DMD in $m d x$ mice include upregulation of utrophin and integrin, and enhanced muscle regeneration (Bulfield et al., 1984; Coulton et al., 1988). Exercise regimens have been used to challenge $m d x$ muscles and exacerbate the disease in order to determine whether a therapy is effective (Brussee et al., 1997; Vandebrouck et al., 2002; De Luca et al., 2003; Okano et al., 2005; Burdi et al., 2006; Hodgetts et al., 2006). Aged $m d x$ mice have a decreased capacity for regeneration and a concomitant increase in severity of the disease. Therefore, the muscular dystrophy exhibited by old $m d x$ mice more closely resembles the myopathy of DMD (Lefaucheur et al., 1995).

In this paper, we delivered to $m d x$ mice by HLV injection pDNA expressing the full-length mouse dystrophin gene. First we evaluated approaches for increasing dystrophin gene delivery and expression in the limb and then we analyzed the efficacy of the gene therapy. Most studies that evaluate muscle strength in $m d x$ mice use the small muscles of the anterior lower leg, the extensor digitorum longus or the tibialis anterior, for contraction studies (Petrof et al., 1993; Dellorusso et al., 2001). However, these small muscles were not transfected well under the conditions used in most of the studies reported here. The large muscles of the leg that transfect best by HLV injection can be tested for an improvement in strength by measuring the whole body tension, also called an escape test, as mice attempt to escape from a stimulus.

Protocols employing Evans blue dye (EBD) are commonly used to characterize muscular dystrophy in mouse models and also as an end point in therapeutic trials conducted in these mice (Matsuda et al., 1995; Straub et al., 1997; Grounds et al., 2008). EBD staining is a direct measure of myofiber membrane integrity. In this paper, we observed by EBD analysis in four independent studies direct functional benefits from the plasmid-delivered dystrophin gene in $m d x$ mice.

\section{Materials and Methods}

\section{Animals}

Breeding pairs of B6Ros.Cg-Dmd $d^{m d x-4 C v} / \mathrm{J}(m d x 4 \mathrm{Cv})$ and C57BL/10ScSn-Dmd ${ }^{m d x} / \mathrm{J}(m d x-10 \mathrm{ScSn})$ mice were obtained from Jackson Laboratories (Bar Harbor, ME) and bred at the University of Wisconsin-Madison (Madison, WI). Male and female $m d x 4 \mathrm{Cv}$ mice were used except where otherwise indicated. Animals had access ad libitum to water and Mouse Diet 5015 chow (PMI Nutrition International, Brentwood, MO) or Teklad Rodent Diet (Harlan Laboratories, Indianapolis, IN). Outbred ICR mice and inbred C57BL/6 mice were obtained from Harlan. Studies were conducted in accordance with the guidelines set forth by the animal care and use committees of the University of Wisconsin and 
Mirus Bio (Madison, WI) and by the National Institutes of Health (Bethesda, MD) Guidelines for the Care and Use of Laboratory Animals.

\section{Hydrodynamic limb vein injection procedure}

Mice were anesthetized with $1-2 \%$ isoflurane (Abbott Laboratories, North Chicago, IL). They were shaved and prepared for surgery and a small latex tourniquet was wrapped tightly around the upper hind limb (above the quadriceps) and secured in place with a hemostat. A small incision was made in the skin between the ankle and the knee to expose a segment of the distal great saphenous vein. A 30-gauge butterfly needle (made by our laboratory as described in Zhang et al., 2004) was then inserted into the distal great saphenous vein, advanced about $0.5 \mathrm{~cm}$, and held in place during the injection. The catheter was connected to a Harvard PHD 2000 syringe pump (Harvard Apparatus, Holliston, MA) and the pDNA-saline solution was injected at a rate of 8 to $15 \mathrm{ml} / \mathrm{min}$. To keep the injection time similar in animals, smaller mice (those weighing approximately $25 \mathrm{~g}$ or less) were injected at a rate of $8 \mathrm{ml} / \mathrm{min}$ and larger mice were generally injected at $12 \mathrm{ml} / \mathrm{min}$. The tourniquet was removed about $2 \mathrm{~min}$ after injection and the skin was closed with 4-0 absorbable suture. The total tourniquet time was about $3 \mathrm{~min}$ and each procedure took $10 \mathrm{~min}$ to complete. When multiple injections were performed in the same leg, injections were done at least 2 weeks apart.

\section{Injection solution volume}

The HLV injection volume for wild-type mice was optimized in 25-g animals. To adjust for larger animals, the following formula was used: $1 \mathrm{ml}+\{[($ body weight $-25 \mathrm{~g}) / 25 \mathrm{~g}] \times 0.5\} \mathrm{ml}$, based roughly on the muscle weight increase relative to the body weight increase. The $m d x$ mice were injected with $1 \mathrm{ml}$ or with $1 \mathrm{ml}+\{[($ body weight $-20 \mathrm{~g}) / 20 \mathrm{~g}] \times 2 / 3\} \mathrm{ml}$. This formula takes into account the larger muscles of $m d x$ relative to wildtype mice and the volume required to obtain similar amounts of muscle swelling. The hind leg muscle mass of a 25-g C57BL/6 mouse is similar to that of a 20-g $m d x$ mouse. As was shown in nonhuman primates, the efficiency of pDNA delivery requires adequate muscle swelling (Vigen et al., 2007). These volume formulas are equivalent to approximately $1.5 \mathrm{ml} / \mathrm{g}$ muscle in the legs of wild-type and $m d x$ mice. To avoid having an excess of injection solution that can leak out of the injection site, this formula was modified somewhat for mice weighing more than $40 \mathrm{~g}$ to $1 \mathrm{ml}+\{[$ (body weight $-20 \mathrm{~g}) / 20 \mathrm{~g}] \times 0.5\} \mathrm{ml}$ because the excess weight in large animals is often fat and not muscle.

\section{Plasmid DNA}

CMV-HMGi-mDys contains the human major immediateearly cytomegalovirus (CMV) enhancer/promoter, murine 3-hydroxy-3-methylglutaryl-Coenzyme A reductase (HMG) intron 1 , mouse dystrophin gene coding sequence, late simian virus 40 (SV40) polyadenylation signal, and kanamycin resistance gene; it is 21,813 base pairs (bp) in size. CMV-SV40i$\mathrm{mDys}$ contains the same CMV enhancer/promoter, along with the 16S/19S SV40 intron, mouse dystrophin coding sequence, late SV40 polyadenylation signal; and kanamycin resistance gene; it is $17,878 \mathrm{bp}$ in size. Control plasmids contained no mammalian promoter and were ampicillin-resistant pUC19 or kanamycin-resistant plasmid pMIR266 that contained a 535-bp stuffer fragment of mouse genomic sequence from the intergenic region of the albumin gene family to enlarge the minimal size plasmid to $2257 \mathrm{bp}$. Luciferase-expressing pCMV-Luc contained the luciferase-encoding gene in the PCI mammalian expression vector (Promega, Madison, WI). All of these plasmids contained the pUC-based ColE1 origin of replication. Preparations of pDNA were purchased from commercial sources. All batches of pDNA passed quality control specifications for less than $100 \mathrm{EU}$ of endotoxin per milligram, and for several preparations we confirmed independently that the levels were at least one magnitude less than this.

\section{Testing pDNA preparations for muscle toxicity}

DNA preparations were tested for toxicity by HLV injection of $500 \mu \mathrm{g}$ of pDNA into the hind leg of an ICR mouse or $2.7 \mathrm{mg}$ into a Sprague-Dawley rat and a group size of six animals. The contralateral legs received HLV injection of saline as a control. Three days later, rodents were anesthetized with 3 to $5 \%$ isoflurane and killed. The skin was then removed from the hind limb and the gastrocnemius muscle (posterior lower leg) was harvested and fixed in 10\% buffered formalin. Specimens were taken from the mid-gastrocnemius muscle and then further processed, embedded in paraffin, sectioned, and stained with hematoxylin and eosin (H\&E). H\&E sections were evaluated by a pathologist. Morphometry (Sigma-Pro imaging program; Systat Software, Chicago, IL) was conducted to quantitate the area of damage.

\section{Rotarod exercise}

Animals were individually exercised on a rotarod (Economex; Columbus Instruments, Columbus, $\mathrm{OH}$ ). Initially the speed of the rotarod was set at $12 \mathrm{rpm}$. If the animal was not able to maintain this speed and fell off the rotarod right away, the rotarod speed was immediately reduced to $8 \mathrm{rpm}$ or further reduced to $6 \mathrm{rpm}$ to determine the highest of these speeds at which the mouse could remain on the rotarod. Once an appropriate speed was found, animals were allowed to run continuously until they fell off. The run time and speed for each animal were recorded.

\section{Treadmill exercise}

Mice were exercised at $8-12 \mathrm{~m} / \mathrm{min}$ for $10-30 \mathrm{~min}$ by running uphill at a $5^{\circ}$ angle on a treadmill (IITC model 800; IITC Life Science, Woodland Hills, CA). An electric shock bar grid at the end of the tread delivered a mild shock to mice if they stopped running. The shock bar was customized to reduce the intensity of the electrical stimulus (maximum, $200 \mathrm{~V}$ ) by adding a $100-\Omega$ resistor to limit the current on the grid to a maximum of $2 \mathrm{~mA}$.

\section{Whole body tension}

Muscle forces were measured as the amount of whole body tension force (WBT) produced by the mice when they tried to escape from a stimulation. The tail of the mouse was connected to a BIOPAC Systems (Goleta, CA) transducer with 4-0 silk thread (one end of the thread was tied to the tail and the other end was tied to the transducer). Each mouse was placed into a small tube constructed of a metal screen with a grid spacing of $2 \mathrm{~mm}$. The length of the tube was 
$16 \mathrm{~cm}$ and the diameter was $3.5-4.5 \mathrm{~cm}$. The tube was taped to a table. The mice entered the apparatus and exerted a small resting tension on the transducer. A forward movement could be reproducibly evoked by pinching the tail with a forceps. Each mouse remained in the tube for $5 \mathrm{~min}$, during which 15-20 forward pulling tensions were evoked (with 15- to 20-sec intervals). The WBT was determined from the average of the five highest forward pulling tensions divided by body weight (millinewtons per gram). The WBT test was performed three times, once per week, before the HLV injections and three times afterward. For each mouse, the average of the three tests before gene delivery was compared with the average of the three tests afterward.

\section{$E B D$ injection procedure}

A $5-\mu \mathrm{g} / \mu \mathrm{l}$ concentration of Evans blue dye (cat. no. E2129; Sigma-Aldrich, St. Louis, MO) prepared in physiological saline was injected intravenously through the tail vein by means a $1-\mathrm{cm}^{3}$ syringe with a 30 -gauge needle. Injections were performed $1 \mathrm{hr}$ before or 20-30 min after exercising the mice. Injection after exercise was preferable because some mice were unable to run or died when injected before exercise. The volume to inject into each mouse was determined by the weight of the animal: $50 \mu \mathrm{l} / 10 \mathrm{-g}$ body weight. Mice were killed $24 \mathrm{hr}$ after EBD injection except where otherwise indicated.

\section{Creatine kinase measurement}

Blood was collected for creatine kinase (CK) measurements by retro-orbital bleed after anesthetizing mice briefly with 1-2\% isoflurane. CK levels were monitored with an Ektachem DT60 analyzer (Eastman Kodak, Rochester, NY).

\section{Animal sacrifice and tissue preparation}

Mice were anesthetized with 3 to $5 \%$ isoflurane and killed by cervical dislocation. The skin was then removed from the hind limb to expose the muscles. All muscles of the hind leg from above the quadriceps down to the ankle were divided into five groups: (1) the anterior group of muscles of the upper leg (includes the quadriceps, on average $20 \%$ of the leg muscle mass), (2) the posterior group of muscles of the upper leg (includes the biceps femoris, $26 \%$ of leg), (3) the medial group of muscles of the upper leg (includes the gracilis and adductor muscles, 24\%), (4) the posterior group of muscles of the lower leg (includes the triceps surae: gastrocnemius, soleus, and plantaris, 20\%), and (5) the anterior group of muscles of the lower leg (primarily the tibialis anterior and extensor digitorum longus, 9\%). Muscle for cell counting was immediately frozen in Tissue-Tek O.C.T. compound (cat. no. 4583; Sakura Finetek, Torrance, CA) on liquid nitrogen and then stored at $-80^{\circ} \mathrm{C}$.

\section{Immunohistochemistry and cell counting}

Cryostat sections $(8-10 \mu \mathrm{m})$ were cut and fixed in $2-4 \%$ formalin for 3-5 min. Dystrophin in the tissue sections was detected with a 1:100 dilution of rat anti-dystrophin polyclonal antibodies (generated by HLV injection of dystrophinexpressing pDNA) as the primary antibody and a 1:100 dilution of fluorescein isothiocyanate (FITC)-conjugated goat anti-rat IgG (cat. no. F6258; Sigma-Aldrich) for the secondary antibody. Some muscle sections were stained with a 1:100 dilution of mouse polyclonal antibodies against mouse dystrophin for $60 \mathrm{~min}$ and a 1:100 dilution of FITC-conjugated goat anti-mouse IgG as the secondary antibody (Fab specific, cat. no. F8771; Sigma-Aldrich) and incubated for $40 \mathrm{~min}$. A Nikon Diaphot-TMD inverted microscope with an FITC filter was used (excitation, $480 \pm 20 \mathrm{~nm}$; emission, $535 \pm 25 \mathrm{~nm}$ ) to evaluate sections for dystrophin staining and to obtain electronic images, and a Texas Red filter was used for EBDpositive cell counting. Myofibers were counted in 10 or 11 microscope views across the diameter of the mid-section of each of the five groups of muscles in microscope views at $\times 160$ magnification.

\section{Immunoblotting}

After tissue sections were taken for immunohistochemistry, the remaining muscle was evaluated by immunoblotting. Protein was extracted from $m d x$ muscle of the hind limb by grinding the tissue with a mortar and pestle chilled with liquid nitrogen. Extraction buffer (7.5 mM Tris, 20\% glycerol, $15 \%$ sodium dodecyl sulfate [SDS], $0.1 M$ dithiothreitol [DTT], and Complete protease inhibitor [cat. no. 11-697 498 001; Roche Diagnostics, Indianapolis, IN]) was added to the powdered muscle $(20 \mu \mathrm{l} / \mathrm{mg}$ tissue) and incubated at ambient temperature for $10-15$ min while inverting several times to mix, and then heated at $100^{\circ} \mathrm{C}$ for $3 \mathrm{~min}$. This solution was passed 20 times through a 20-gauge needle to shear the DNA, and then centrifuged at $10,000 \times g$ for $5 \mathrm{~min}$. The supernatant was assayed for protein concentration, using an RC DC protein assay kit (Bio-Rad, Hercules, CA). Protein extracts for dystrophin standard were prepared from normal C57BL/ 6 and $m d x 4 \mathrm{Cv}$ or $m d x-10 \mathrm{ScSn}$ mouse muscle. Various percentages of normal mouse protein (1-25\%) were then combined with the appropriate amount of $m d x$ mouse protein. The samples shown in some of the blots had an insufficient amount of SDS and DTT, resulting in some smearing of the dystrophin protein at the top of the gel. This problem was corrected by diluting samples in extraction buffer. Samples were electrophoresed in a 3-8\% Tris-acetate SDSpolyacrylamide gel (Invitrogen, Carlsbad, CA), with $25 \mu \mathrm{g}$ of total protein loaded per well. Proteins were transferred onto polyvinylidene difluoride (PVDF) at $40 \mathrm{~V}$ for $2 \mathrm{hr}$ in NuPage transfer buffer (Invitrogen) with $0.1 \%$ SDS added. Primary antibody NCL-DYS1 (Novocastra Laboratories, Newcastle upon Tyne, UK) was diluted 100-fold. The affinity-purified, peroxidase-conjugated, goat anti-mouse IgG secondary antibody (Sigma-Aldrich) was diluted 1000-fold. Dystrophin was detected by enhanced chemiluminescence (ECL Plus Western blotting detection reagents; GE Healthcare Life Sciences, Piscataway, NJ) using Kodak BioMax MS film (Carestream Health, Rochester, NY). Subsequently, the membrane was stained with Ponceau S red (Fluka; Sigma-Aldrich) and the gel with Brilliant Blue G stain (Sigma-Aldrich) to verify that the proteins transferred evenly. For quantitation, Carestream Molecular Imaging software (Carestream Molecular Imaging, Woodbridge, CT) was used to generate a standard curve for each blot.

\section{Calculations and statistical analysis}

Weighted averages for EBD- or dystrophin-positive myofibers in the hind leg muscles were determined as follows: 
a

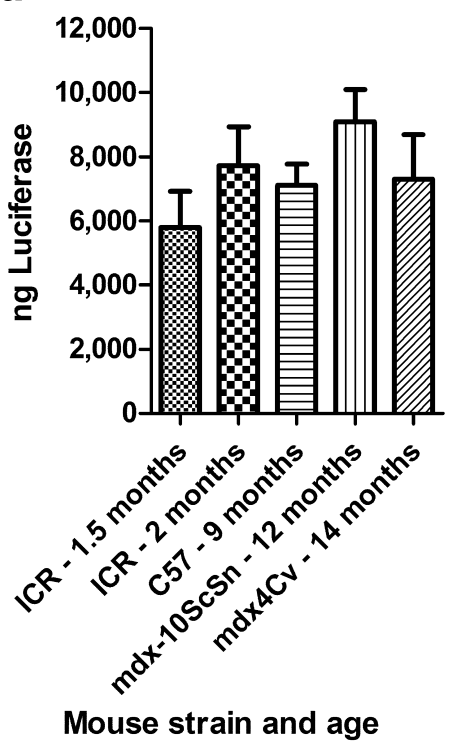

b
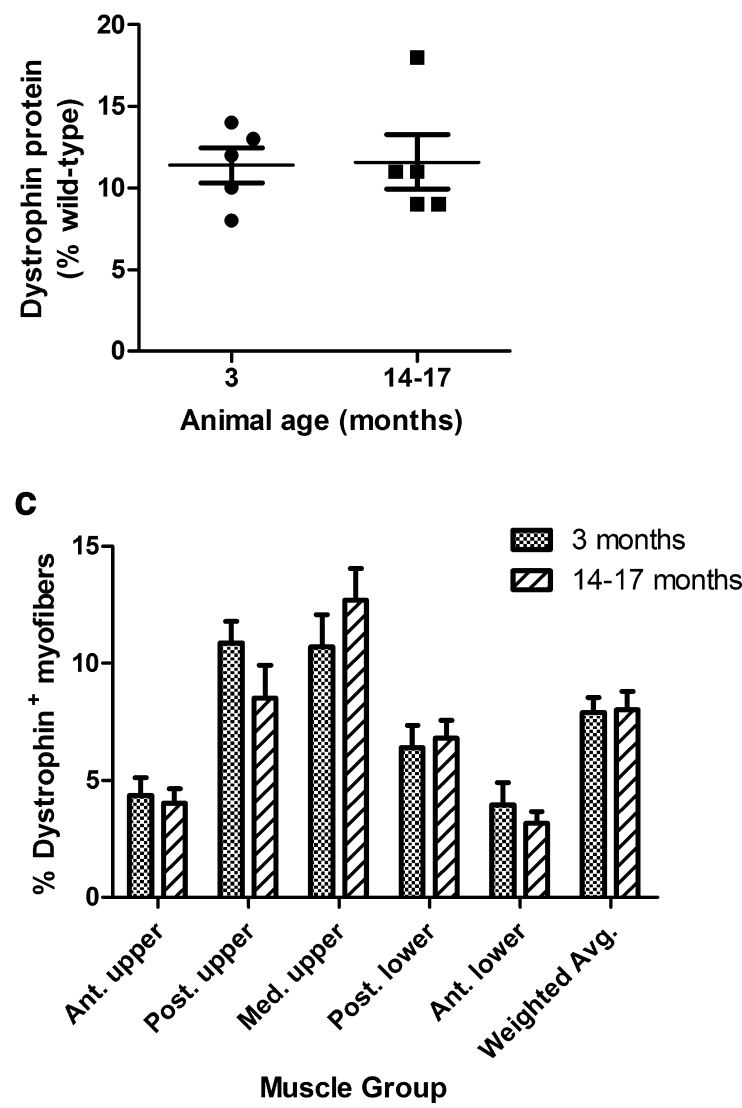

FIG. 1. Gene delivery compared in strains of mice of varying ages. (a) Male ICR, C57BL/6, $m d x-10 \mathrm{ScSn}$, and $m d x 4 \mathrm{Cv}$ mice, of the indicated ages, each received one hydrodynamic limb vein (HLV) injection of $100 \mu \mathrm{g}$ of pCMV-Luc per hind leg (see Table 1, study 1). Mice were killed 1 week later to measure luciferase expression. The $y$ axis shows total luciferase expression in the entire limb, which was determined by summing up the amount of luciferase in each group of muscles. (b and $\mathbf{c}$ ) Young adult and old $m d x 4 \mathrm{Cv}$ mice received two HLV injections of CMV-HMGi-mDys $(300 \mu \mathrm{g} / \mathrm{ml})$ in the same leg (Table 1, study 2). Mice were killed 2 weeks after the last injection. (b) The average dystrophin protein expression in muscle groups $2-4$ (see Materials and Methods) and (c) percentages of Dys ${ }^{+}$myofibers in each group of muscles are shown.

$\left(\sum A_{1} M_{1}+A_{2} M_{2}+A_{3} M_{3}+A_{4} M_{4}+A_{5} M_{5}\right) / M_{\mathrm{t}}$, where $A_{i}$ is the average number of positive myofibers per microscope view in muscle group $i$ and $M_{i}$ is the average weight of that muscle group, and $M_{t}$ is the total weight of all limb muscles. Average values in the text and figures are given \pm standard error. Protection from muscle damage was defined as the percentage of $\mathrm{EBD}^{+}$myofibers in a muscle group from the control leg divided by the percentage of $\mathrm{EBD}^{+}$myofibers in the contralateral muscle group of the dystrophin plasmidinjected leg. The decrease in $\mathrm{EBD}^{+}$myofibers in each group of muscles from the dystrophin plasmid-injected leg relative to the control leg was determined as a percentage reduction, using the following formula: $\left(\% \mathrm{EBD}^{+}\right.$myofibers in control muscle group - \% $\mathrm{EBD}^{+}$myofibers in dystrophin plasmidinjected contralateral muscle group) $/ \% \mathrm{EBD}^{+}$myofibers in control muscle group. Statistical analyses were performed with Prism (GraphPad, San Diego, CA). The $p$ values and correlations were determined with a two-tailed $t$ test, unless otherwise indicated. To accommodate high variability between animals and the non-Gaussian distribution of EBD staining, the Wilcoxon signed rank $t$ test was used to compare contralateral pairs of muscles for statistical analysis.

\section{Results}

The HLV delivery procedure was optimized for wild-type mice by using an injection volume that resulted in high levels of expression from an injected reporter gene plasmid, indicative of the efficiency of pDNA delivery, and low levels of serum creatine kinase (CK), an indicator of muscle damage. Optimal injection conditions are described in Materials and Methods. Data from 156 mice were combined to compare preinjection CK levels with those 1 to 5 days after the HLV injection (see Supplementary Fig. 1a at www.liebertonline. com/hum). The average CK levels were statistically the same before and after the HLV injection, showing no significant muscle damage. This conclusion was supported by histological evaluation of muscle specimens from the gastrocnemius of wild-type mice that were given an HLV injection of saline 3 days prior. As determined by morphometric quantitation, the uninjected legs had $0.03 \%$ damaged muscle and the salineinjected legs had $1.2 \%$ damage, but this difference was not statistically significant ( $p=0.08$; see Supplementary Fig. $1 b$ ). Thus, serum CK levels and histological evaluation showed no significant damage from the HLV injection procedure. 
$m d x$ mice respond to their muscular dystrophy by developing hypertrophic muscles that are larger, relative to wildtype mice. The delivery procedure was then adapted to $m d x$ mice by increasing the injection volume in proportion to the muscle weight and adjusting the injection rate so that the injection delivery procedure would take a similar amount of time in large and small mice (see Materials and Methods). Muscles of dystrophic animals are expected to be more fragile than normal muscle. Therefore, we examined the histology of $m d x$ leg muscles 1 or 3 days after HLV injection of saline into one leg of each mouse. The injection caused no measurable increase in muscle damage (see Supplementary Fig. 1c). Consistent with the results of others, we measured areas of necrotic and regenerating myofibers comprising $2-6 \%$ of the muscle in the uninjected leg. These areas in the contralateral saline-injected legs were indistinguishable from the control legs.

Because of the muscular dystrophy, CK levels in $m d x$ mice are higher than in normal mice. Instead of increasing after an HLV injection, however, CK levels in the $m d x$ mice were lower 1 and 3 days postinjection $(p<0.0001$, one-way ANOVA with Bonferroni multiple comparison test). CK levels decreased from an average of $5566 \pm 344 \mathrm{U} /$ liter before the injection to $4085 \pm 292 \mathrm{U} /$ liter 1 day later and to $3041 \pm$ $302 \mathrm{U} /$ liter on the third day $(n=31-81)$. By the fourth day, CK levels were statistically the same as they were before the injection. The HLV injection procedure in rodents requires minor surgery to expose the great saphenous vein of the hind limb in order to visualize insertion of the needle. The transient reduction in $\mathrm{CK}$ levels was likely the result of decreased activity as mice were recovering from the surgical procedure. Mice are typically active as soon as the anesthesia wears off and a possible reduction in activity was not actually measured.

Another factor that could potentially affect gene expression after pDNA delivery would be a difference in plasmid uptake by fast-twitch compared with slow-twitch myofibers. Dystrophin-expressing pDNA was delivered by HLV to $m d x$ mice to determine whether fast and slow myofibers take up and express pDNA differentially after HLV injection (see Supplementary Materials and Methods at www.liebertonline .com/hum). All fiber types were transfected equally well (see Supplementary Fig. 2).

Experimental details for animal studies are shown in Table 1 and are referred to by study number throughout this paper.

\section{Gene delivery in young and old $\mathrm{mdx}$ mice}

As with humans, the DMD disease phenotype becomes more severe in aged $m d x$ mice. To determine whether animal age affects the efficiency of gene delivery to skeletal muscles, two strains of normal mice and two strains of $m d x$ mice were each injected with the same dose of luciferase-expressing plasmid (Fig. 1a; Table 1, study 1). The mice varied in age from 1.5 to 14 months. The total amount of luciferase protein produced in the leg was similar in all strains and all ages ( $p=0.37$; Fig. 1a).

Dystrophin gene delivery was then compared in young adult and old $m d x$ mice (Fig. $1 \mathrm{~b}$ and c; Table 1, study 2 ). In this study all mice received two HLV injections in one hind leg with the same $300-\mu \mathrm{g} / \mathrm{ml}$ concentration of CMV promoterdriven mouse dystrophin expression plasmid CMV-HMGi-
mDys. Injection volumes were adjusted to accommodate the larger size of the old mice, which weighed approximately twice as much as the young adults. The pDNA per target volume was fixed, so larger animals with a larger target muscle mass received more pDNA than did smaller animals. The younger mice produced $11.4 \pm 1.1 \%$ dystrophin protein, relative to a wild-type mouse, and the aged mice produced $11.6 \pm 1.7 \%$ dystrophin ( $p=0.92$; Fig. $1 b$ ). The percentages of myofibers that expressed dystrophin, an average of $8 \%$ in the whole leg, and their distribution within the legs were similar for both age groups (Fig. 1c). Gene delivery was equally effective in the aged and young adult $m d x$ mice when the pDNA dose was adjusted for the increased muscle mass in the old mice. The $300-\mu \mathrm{g} / \mathrm{ml}$ concentration of pDNA was less than the optimal dose of approximately $500 \mu \mathrm{g} / \mathrm{ml}$. A larger dose results in higher percentages of transfected myofibers in the anterior thigh and anterior lower leg muscles (our unpublished observation).

In conclusion, age does not affect the efficiency of pDNA gene delivery in the $m d x$ mouse model.

\section{Dystrophin expression from multiple gene deliveries}

Using CMV-SV40i-mDys, we compared dystrophin expression in the hind leg muscles of $m d x$ mice that received one or three HLV injections of this pDNA (Fig. 2a-c; Table 1, study 3). The three large groups of muscles that transfect best in rodent hind legs are the posterior and medial thigh muscles and the posterior lower leg muscles, which together comprise $71 \%$ of the leg muscles. For convenience, we refer to these as muscle groups 2, 3, and 4 (see Materials and Methods for details). The average percentages of dystrophinexpressing myofibers in these muscles increased from $5.7 \pm 0.6 \%$ after one injection to $11.8 \pm 0.9 \%$ after three injections. The amount of dystrophin protein produced in these muscles increased from $4 \pm 1 \%$ after one injection, relative to a normal mouse, to $14 \pm 1 \%$.

In $m d x$ mice that were injected six times with dystrophinexpressing pDNA, this time with the larger CMV-HMGimDys (Fig. 2d-f; Table 1, study 4), up to $51 \%$ of myofibers expressed dystrophin in some of the large muscles (Fig. 2d), although other muscles expressed less (Fig. 2e). The average percentages of expressing myofibers in muscle groups 2-4 was $13.3 \pm 1.9 \%$. More than one-third of these muscles produced at least $20 \%$ of the wild-type amount of dystrophin protein ( $n=11$ mice, 33 groups of muscles). These experiments show that the mice tolerate repeated injections well, and that multiple gene deliveries increase dystrophin expression.

\section{Comparing introns in the plasmid constructs}

The plasmids CMV-SV40i-mDys and CMV-HMGi-mDys differ only in the intron that they contain, which in both cases is positioned just upstream of the dystrophin cDNA. CMV-SV40i-mDys contains a 96-bp hybrid intron from simian virus 40 (SV40i). CMV-HMGi-mDys contains the 4141-bp human HMG1 intron (HMGi) and, as a result, is larger than the SV40i construct. The two CMV-mouse dystrophin plasmids were compared by using equal molar concentrations, one injection per mouse, and expression was evaluated 2-6 weeks after injection (Fig. 3; Table 1, study 5). 


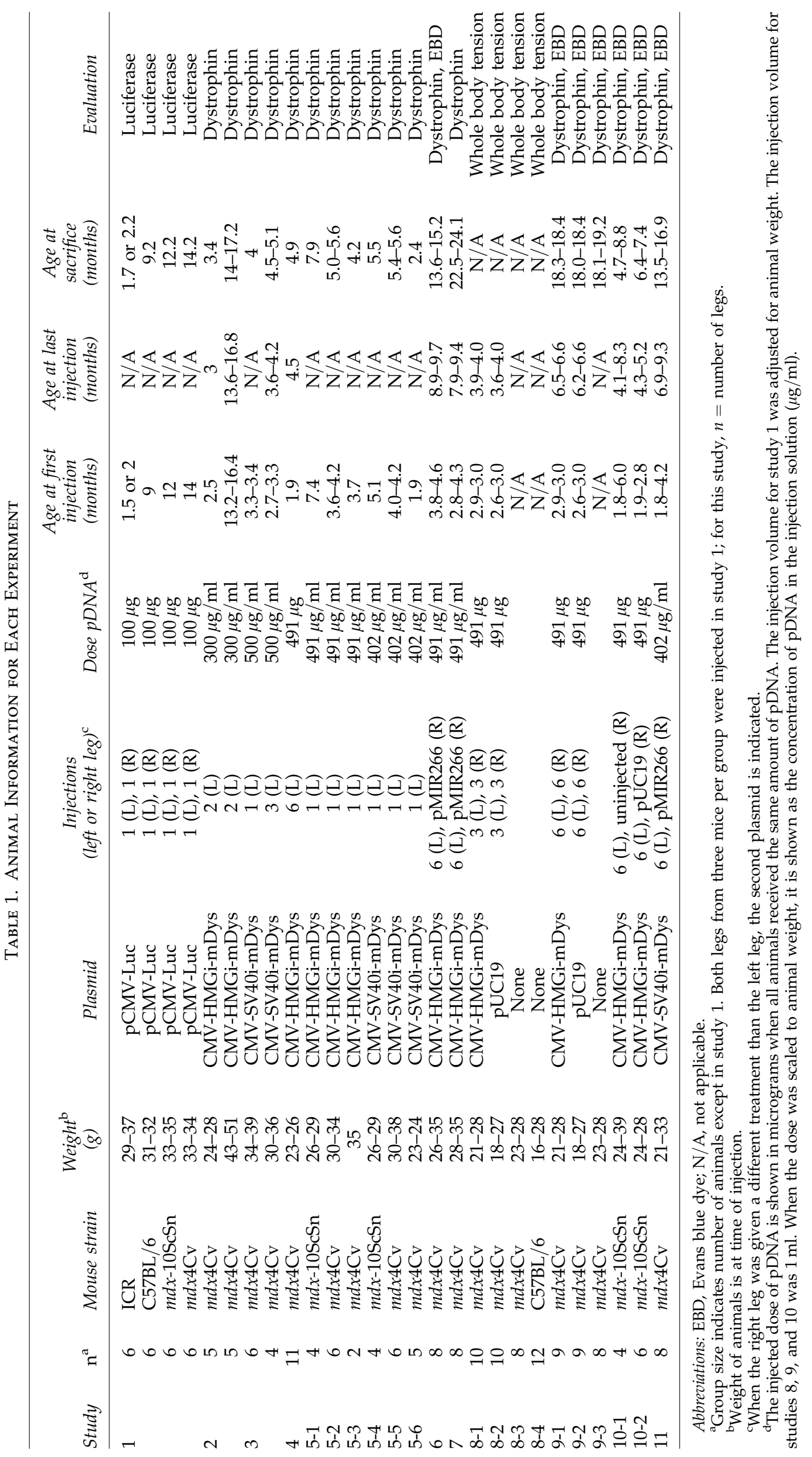


a

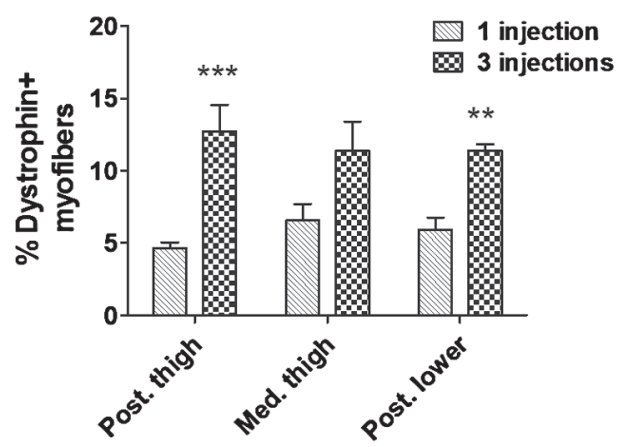

b

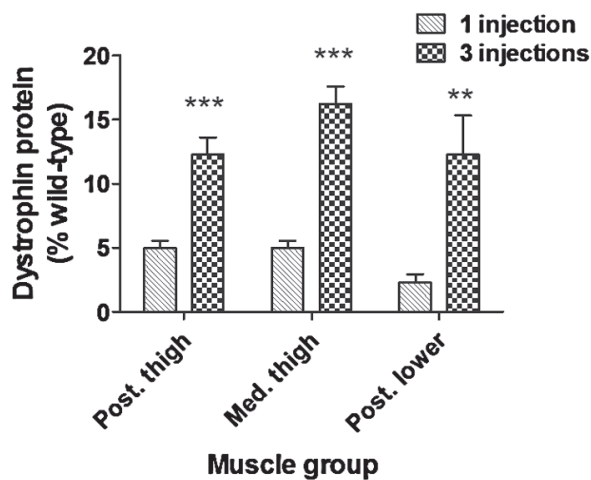

d

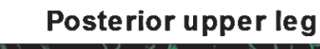

e

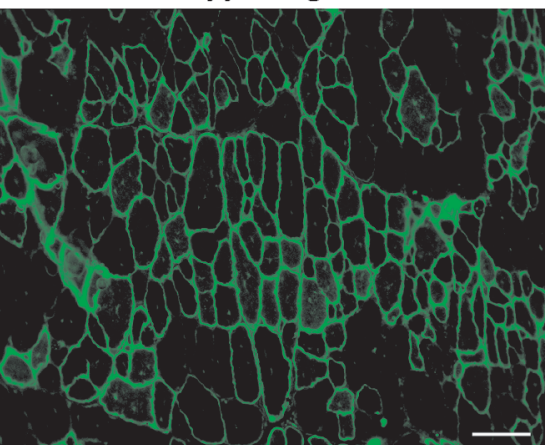

Posterior lower leg

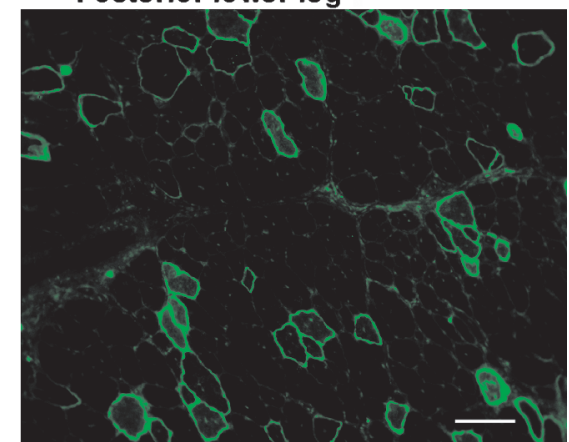

f

CMV-SV40i-mDys injected $3 \mathrm{X}$

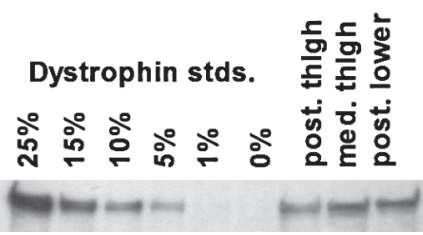

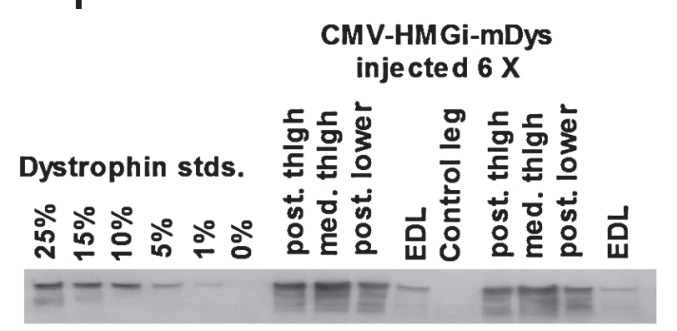

FIG. 2. Dystrophin expression. (a-c) Male $m d x$ mice were injected once or three times by HLV with CMV-SV40i-mDys $(500 \mu \mathrm{g} / \mathrm{ml})$ in a volume adjusted for animal weight and then were killed 4 weeks after the last injection (Table 1, study 3). The average percentages of (a) dystrophin-positive myofibers and (b) dystrophin protein are shown by muscle group. Statistical analysis was performed with a two-tailed $t$ test $\left.{ }^{* *} p<0.01,{ }^{* * *} p<0.001\right)$. (c) Western blot shows representative expression in one animal after three injections. (d-f) $m d x$ mice were injected six times with $491 \mu \mathrm{g}$ of CMV-HMGi-mDys in $1 \mathrm{ml}$ of injection solution and evaluated 2 weeks after the last injection (Table 1, study 4). Shown are (d) an area of high expression in the posterior upper leg and (e) less expression in the posterior lower leg of the same mouse. Scale bars, $100 \mu \mathrm{m}$. (f) Western blot of samples from two of the mice in study 4 shows dystrophin expression. The extensor digitorum longus (EDL) is in the anterior lower leg.

Expression from both plasmids is stable during this period of time (data not shown). Delivery is less efficient with larger plasmids (Zhang et al., 2004). Despite this, the mice that were injected with CMV-HMGi-mDys had on average nearly $50 \%$ more Dys ${ }^{+}$myofibers than those injected with CMV-SV40imDys $(p=0.0011)$. In addition to having more Dys ${ }^{+}$myofibers, the mice injected with CMV-HMGi-mDys produced 2.3 times more dystrophin protein than those injected with the construct containing the smaller SV40i $(p=0.0003)$. The HMG1 intron was more effective for gene expression than the SV40 intron. The percentages of $\mathrm{Dys}^{+}$myofibers increased from 4 to $6 \%$ after one injection when a higher, more optimal dose of CMV-SV40i-mDys $(500 \mu \mathrm{g} / \mathrm{ml})$ was used (compare Fig. 3 with Fig. 2a). However, even with the optimized dose of CMV-SV40i-mDys, this plasmid produced approximately half as much dystrophin protein as the HMGicontaining plasmid ( $p=0.03, n=6-12$; compare Fig. $2 b$ with Fig. 3).

\section{Stability of plasmid-driven dystrophin expression}

The longevity of dystrophin expression from the CMVHMGi-mDys plasmid was evaluated by injecting $m d x$ mice six times with this pDNA and then killing them from 0.5 to 15 months after the last injection (Fig. 4). One group of mice was injected at the usual 2-week intervals and killed 2 weeks after the last gene transfer, which was 3 months after the first injection (Table 1, study 4). These mice were compared with 


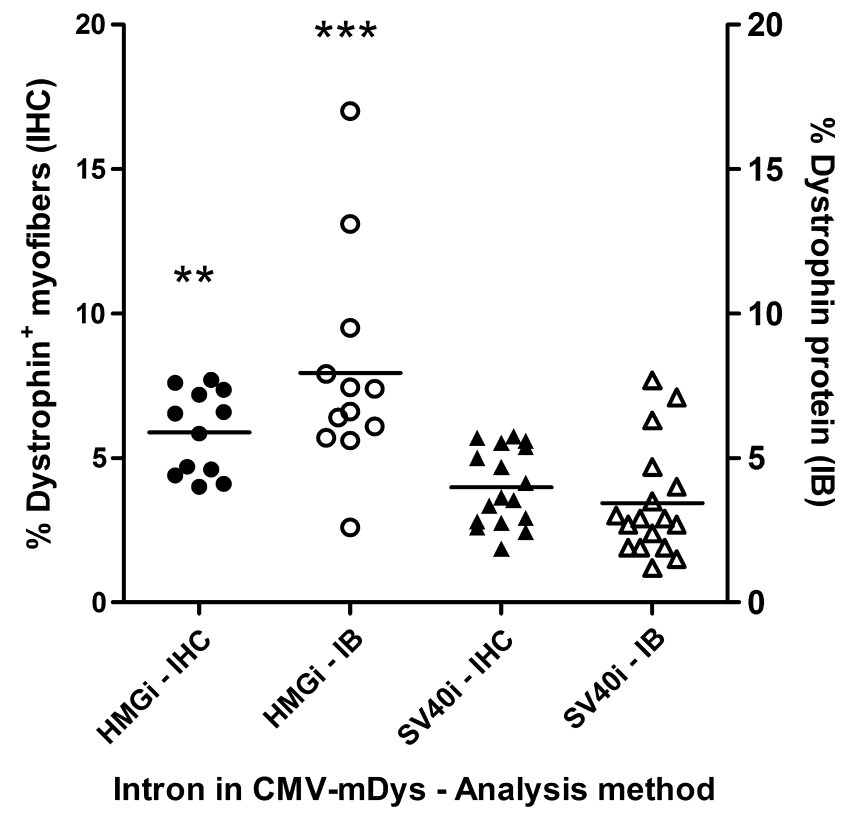

FIG. 3. Comparing introns in CMV-mDys expression plasmids. $m d x$ mice received one HLV injection of CMVHMGi-mDys at $491 \mu \mathrm{g} / \mathrm{ml}(\mathrm{HMGi}, n=12$; Table 1 , studies 51 to $5-3$ ) or of CMV-SV40i-mDys at $402 \mu \mathrm{g} / \mathrm{ml}$ (SV40i, $n=17$; Table 1, studies 5-4 to 5-6), which were equal molar concentrations. The mice were killed 2-6 weeks after the injection and dystrophin expression was evaluated by immunohistochemistry (IHC) or immunoblotting (IB). Each data point represents the weighted average expression of dystrophin per mouse in muscle groups 2-4. Statistical analysis between groups was performed with a two-tailed $t$ test $\left({ }^{* *} p<0.01,{ }^{* * *} p<0.001\right)$.

groups that were injected with the pDNA over the course of 5 months and then killed 5 months (Table 1, study 6) or 15 months (Table 1, study 7) after the last injection. Those evaluated 5 months after the last injection were 14 months old at sacrifice and those evaluated 15 months after the last injection were 23 months old. The latter time point was nearly the end of the mouse's life span. The average percentages of $\mathrm{Dys}^{+}$myofibers in the muscle groups that transfect well was the same in mice evaluated at the earliest time point and in those that had been injected over the course of 5 months and evaluated 5 months after the last injection (Fig. 4a). Both groups had an average of $13 \%$ Dys $^{+}$ myofibers $(p=0.93)$ and $15-17 \%$ dystrophin protein in these muscles $(p=0.32)$.

The oldest mice, evaluated when they were 23 months old (Table 1, study 7), had an average of $16.5 \%$ Dys $^{+}$myofibers in their medial upper leg muscles, with higher percentages in some areas (Fig. $4 \mathrm{~b}$ and e). This was a similar percentage as in the mice evaluated 5 months after the last gene transfer and 2.5 times more than in the mice killed at the earliest time point $(p<0.0001$; Fig. $4 \mathrm{~b})$. The oldest group of mice produced an average of $26 \%$ of the normal amount of dystrophin protein in their posterior lower leg muscles at sacrifice, nearly $60 \%$ more than the mice that were evaluated at either the early or the intermediate time point ( $p=0.008$; Fig. $4 \mathrm{c}$ and $d$ ). Thus, dystrophin expression after six injections of CMV-HMGi-mDys in at least some groups of muscles was not only stable for the life of the animals, but even appeared to increase in the oldest animals.

\section{Immune response to dystrophin}

Most $m d x$ mice injected with dystrophin-expressing pDNA begin to generate antibodies to the dystrophin 2 weeks after gene transfer, whether the plasmid is injected by intraarterial injection (Zhang et al., 2004) or by HLV injection (see Supplementary Table 1 at www.liebertonline.com/hum). However, long-term expression studies described previously (Fig. 2) show additional expression from the second and third HLV deliveries of dystrophin-expressing pDNA that were performed after the period of time in which an antibody response was previously shown to occur.

To address the possibility of a myositis response to expression of a foreign dystrophin gene, $m d x$ and wild-type mice and rats were injected with plasmids expressing human or mouse dystrophin or a reporter gene, or with nonexpressing control plasmids. We observed that some batches of pDNA caused muscle damage that was evident by histology as areas of regenerating myofibers 3-4 days after a large dose of pDNA was delivered by HLV injection $(0.5 \mathrm{mg}$ in a mouse or $2.7 \mathrm{mg}$ in a rat), but this was not myositis and did not depend on expression of any gene product (C.I. Wooddell, V. Subbotin, M. Sebestyen, G. Zhang, J.B. Griffin, T. Huss, and J.A. Wolff, unpublished data). The apparent pDNA-associated toxicity was completely batch dependent and not due to expression of dystrophin or to the pDNA itself. The toxicity was unlikely to be due to endotoxin because some preparations containing as little as $0.2 \mathrm{EU}$ of endotoxin per milligram caused muscle damage whereas other batches with comparable amounts or more caused no damage.

\section{Muscle function studies}

Four independent studies were performed to assess muscle function in $m d x$ mice injected with a pDNA encoding murine dystrophin (Table 1, studies 6, 8, 10, and 11). A fifth study (Table 1, study 9) was performed with the same mice used for study 8 . The whole body tension test was performed first to evaluate leg muscle strength in young adult $m d x$ mice that were naive or that received three HLV injections in both hind legs with $491 \mu \mathrm{g}$ of either dystrophin-expressing CMVHMGi-mDys or control pUC19 (Table 1, study 8; Fig. 5). These were compared with wild-type mice. In this kind of evaluation, both hind legs are injected with the same pDNA. Animal-to-animal variation is high, so the mice were tested before and after the treatment (Fig. 5a). Overall, $m d x$ mice and wild-type mice had increased pulling strength at the later time point (after HLV injections in the mice that were injected), likely because both strains grew larger during the 6 weeks in which injections were performed. The pulling force was normalized to animal weight to allow comparison of animals that differed in size. $m d x$ mice were randomly divided into treatment groups. Although the control group of mice that later received pUC19 exerted more pulling force before the injections than the other groups of $m d x$ mice, their normalized strength did not increase significantly after the injections (Fig. 5b; $p=0.844$; Table 1 , study $8-2$ ), nor did that of the uninjected $m d x$ mice ( $p=0.998$; Table 1 , study 8-3). The dystrophin plasmid (Dys)-injected $m d x$ mice, however, pulled away with $27 \%$ more force after gene delivery, 

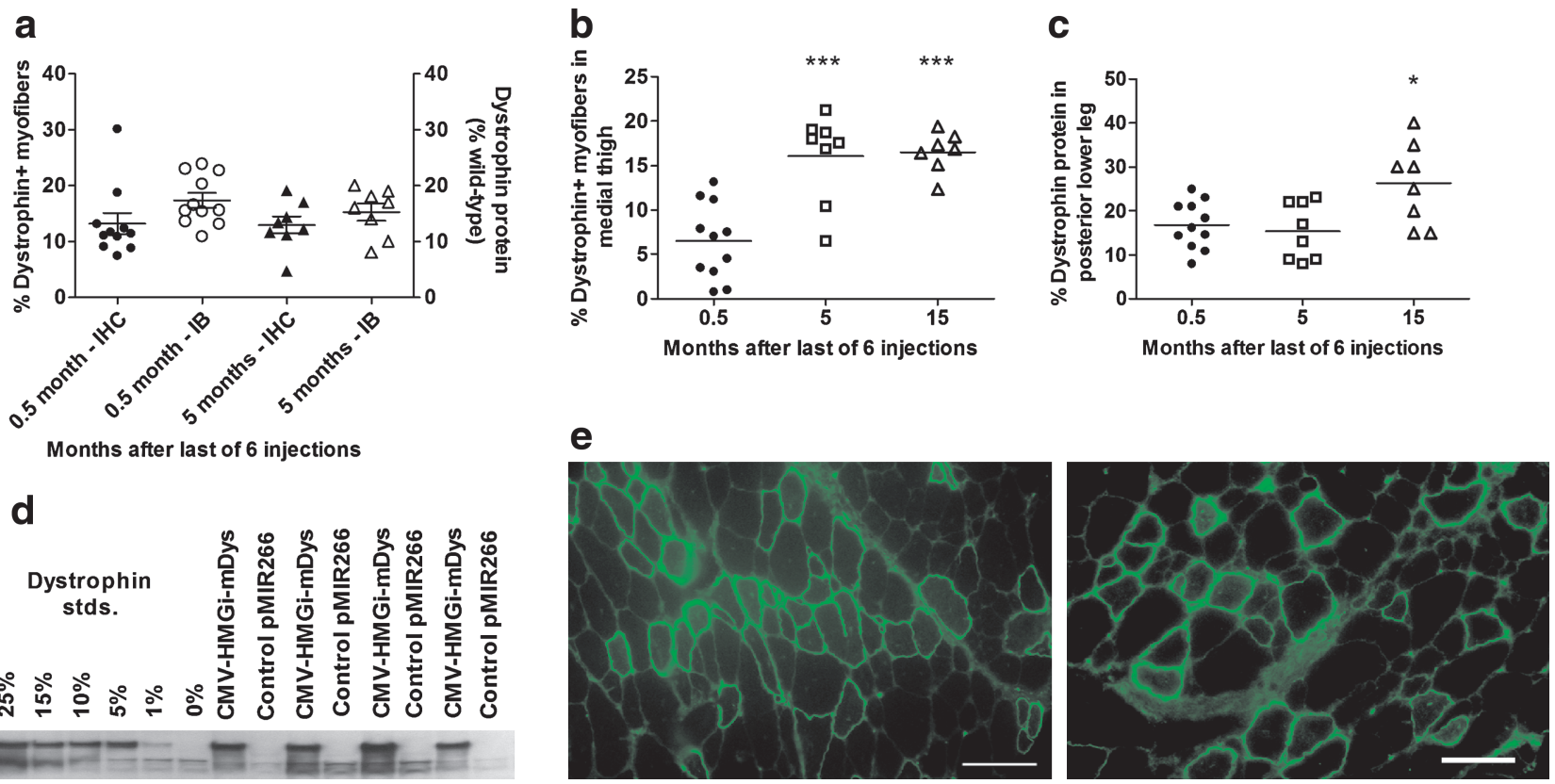

FIG. 4. Longevity of dystrophin expression from plasmid constructs. $m d x$ mice received six HLV injections of CMV-HMGi$\mathrm{mDys}(491 \mu \mathrm{g} / \mathrm{ml})$ and were evaluated for dystrophin expression at 0.5 months (Table 1, study 4$), 5$ months (Table 1, study 6), or 15 months (Table 1, study 7) after the last injection. (a) In the short-term evaluation, injections were 2 weeks apart and mice were killed to determine dystrophin expression 0.5 months after the last injection. For long-term evaluation, mice received the six HLV injections over the course of 5 months and were killed 5 months after the last injection. Expression is shown as the weighted average in muscle groups $2-4$. (b-e) In addition to the mice described in (a), a third group of mice was injected over the course of 5 months and evaluated 15 months after the last injection. (b) Dystrophin-expressing myofibers in the medial thigh muscles of each mouse and (c) dystrophin protein in the posterior lower leg muscles are shown. Statistical analysis between groups was performed with a two-tailed $t$ test $\left({ }^{*} p<0.05,{ }^{* * *} p<0.001\right)$. (d) Immunoblot shows dystrophin extracted from the posterior lower leg muscles of the Dys-injected legs and empty vector pMIR266-injected legs of four representative mice evaluated 15 months after the last injection. (e) Sections stained for dystrophin from the medial thigh muscles of two mice evaluated 15 months after the last injection. Scale bars, $100 \mu \mathrm{m}$.

compared with the force measured before gene delivery (Fig. $5 b ; p=0.0129)$. Nine of the 10 mice had greater pulling strength after gene delivery. Before injections, the pulling force of the $m d x$ mice that later received the Dys pDNA was $66 \%$ that of the wild-type mice. After three Dys injections, their pulling force was $88 \%$ that of the wild-type mice (Fig. $5 a)$. The pulling force of the uninjected $m d x$ mice was initially $63 \%$ that of wild-type mice and at the later time point was nearly the same, $68 \%$ (Fig. 5a). The normalized strength of the wild-type mice decreased slightly at the later time point,
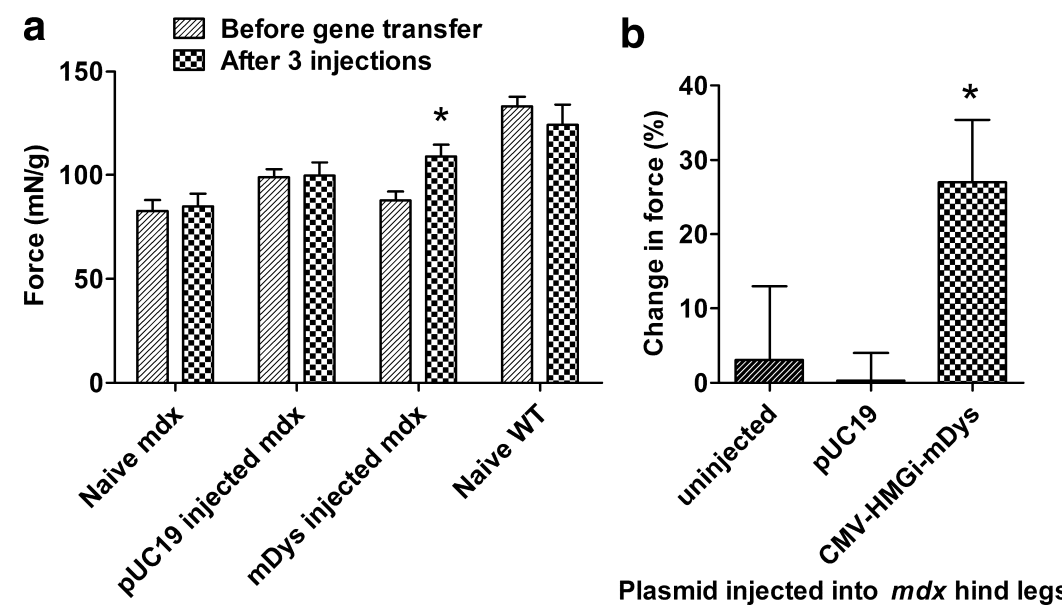

FIG. 5. Muscle strength testing. Groups of $m d x$ mice were uninjected or injected three times in each leg with $491 \mu \mathrm{g}$ of empty vector (pUC19) or CMV-HMGi-mDys (Table 1, study 8). Wild-type (WT) C57BL/6 mice were uninjected. Before gene delivery and again beginning 2 weeks after the last delivery, the mice were tested for whole body pulling force, shown as (a) force relative to body weight $(\mathrm{mN} / \mathrm{g})$ and as $(\mathbf{b})$ the percent change in force. Statistical analysis was performed with a paired, twotailed $t$ test to compare pulling force before and after treatment $\left({ }^{*} p<0.05\right)$. 
a

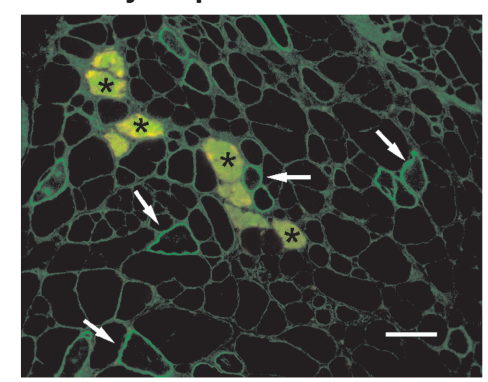

b

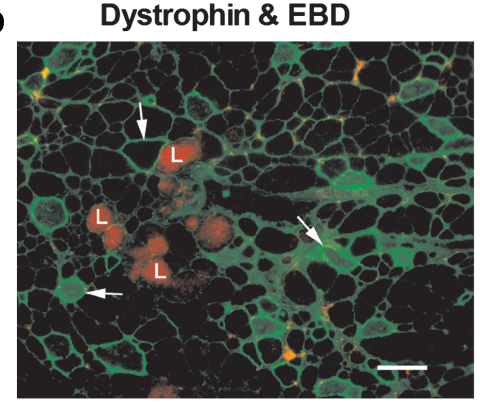

C

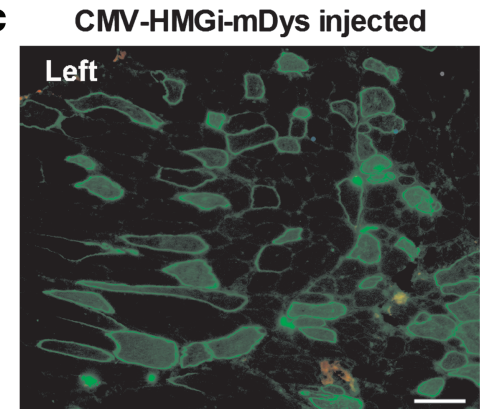

$H \& E$

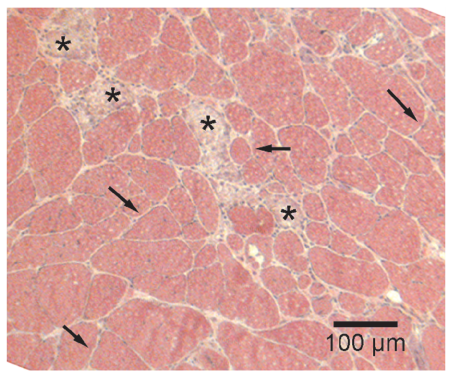

$H \& E$

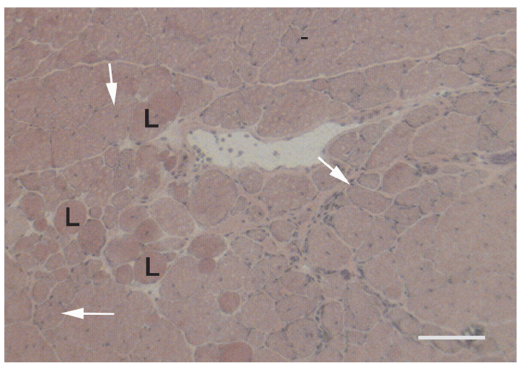

Uninjected control

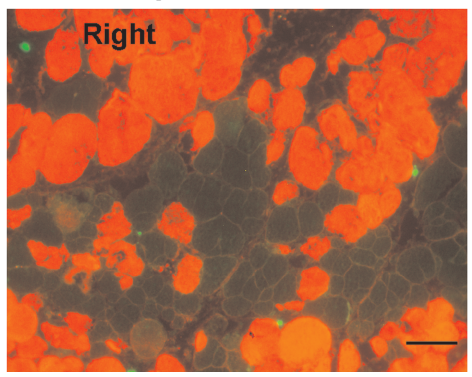

FIG. 6. Evans blue studies in $m d x$ mice. (a and $\mathbf{b}) m d x 4 \mathrm{Cv}$ mice were injected six times in each leg with $491 \mu \mathrm{g}$ of CMVHMGi-mDys, beginning when they were 3 months old (Table 1, study 9-1). When they were 18 months old, they were exercised on a treadmill at $12 \mathrm{~m} / \mathrm{min}$ for $10 \mathrm{~min}$, injected with Evans blue dye (EBD) the next day, and killed for evaluation $24 \mathrm{hr}$ after this. Consecutive muscle sections were stained for dystrophin (FITC) (left), or stained with hematoxylin and eosin for evaluation of the histology $(r i g h t)$. The FITC images were overlapped with images of EBD autofluorescence from the same muscle sections. FITC-labeled anti-mouse IgG secondary antibody labeled dystrophin-expressing myofibers (arrows). This secondary antibody also labeled the endogenous IgG antibodies that accumulated in damaged myofibers $\left(^{*}\right)$ in (a). Myofibers staining darkly with EBD $\left(^{*}\right)$ and those staining only lightly $(\mathrm{L})$ are shown in the merged images and corresponding histology sections from the medial thigh muscles of the same mouse. (c) An $m d x-10 \mathrm{ScSn}$ mouse was injected six times with $491 \mu \mathrm{g}$ of CMV-HMGi-mDys in the left leg, beginning when it was 2 months old, and the right leg was uninjected (Table 1, study 10-1). Two weeks after the last injection, the mouse was exercised on a rotarod at $9 \mathrm{rpm}$ for $30 \mathrm{~min}$, injected with EBD, and killed $24 \mathrm{hr}$ later. Overlapping images of dystrophin staining (FITC) and EBD fluorescence are from contralateral posterior lower leg muscles of the left and right legs. None of the myofibers were EBD positive in this microscope view of the CMV-HMGimDys-injected leg. Scale bars, $100 \mu \mathrm{m}$.

but the difference was not significant $(p=0.34)$ and was mostly due to an increase in weight.

Evans blue dye (EBD) was used to measure the degree of protection afforded the dystrophic leg muscles that received dystrophin-expressing pDNA (Figs. 6 and 7). Exercise protocols were used to challenge the hind leg muscles in these studies and cause damage in myofibers that were not protected by adequate dystrophin expression. Damaged myofibers are permeable to the EBD-albumin conjugate as well as to serum proteins (McGeachie et al., 1993; Straub et al., 1997; Wooddell et al., 2009).

The same mice that were previously used to perform the whole body tension study thereafter received three addi- tional HLV injections of the same plasmids (Table 1, studies 9-1 and 9-2). When these mice were 18 months old, they were exercised on a treadmill, injected with EBD, and subsequently evaluated for muscle damage by counting EBDpositive myofibers in the hind legs. The average number of myofibers expressing dystrophin in large muscle groups $2-4$ was only $4.7 \pm 0.5 \%$. The pDNA dose in these animals had not been adjusted for their increasing weight as they grew older. Even so, the Dys-injected mice (Table 1, study 9-1) had $73 \%$ fewer $\mathrm{EBD}^{+}$myofibers in their medial thigh muscles than the age-matched pUC19-injected $m d x$ mice $(p=0.0015$; Table 1, study 9-2) and 60\% fewer than age-matched uninjected $m d x$ mice ( $p=0.0026$; Table 1 , study 9-3). As shown in 

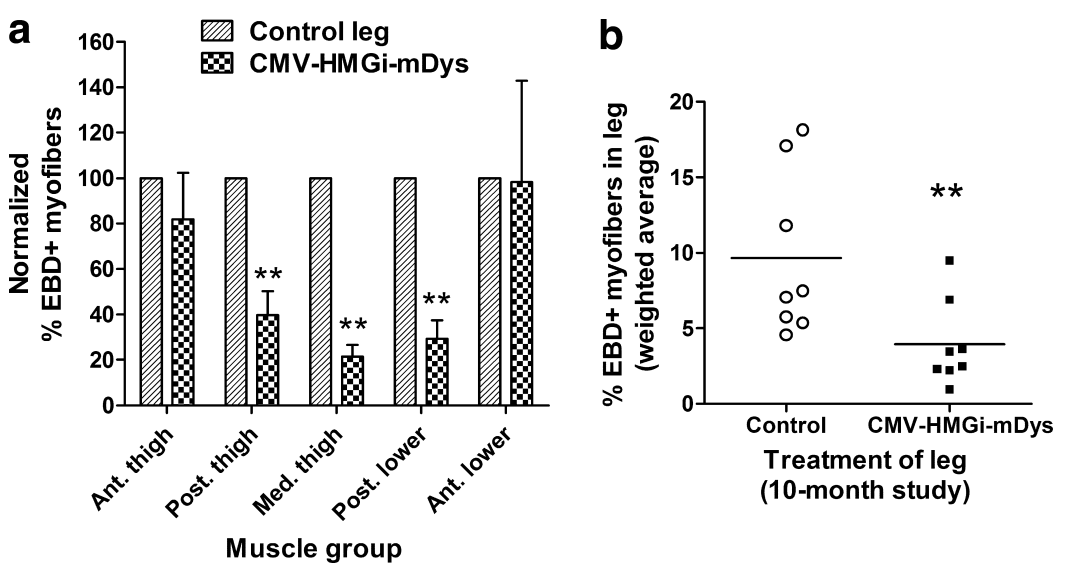

FIG. 7. Reduction in Evans blue staining. (a and b) In a long-term study, $m d x$ mice were injected six times with CMVHMGi-mDys $(491 \mu \mathrm{g} / \mathrm{ml})$ in one leg and with the same dose of nonexpressing control plasmid pMIR266 in the other leg (Table 1, study 6). Ten months after the first gene transfer, the mice were exercised on a treadmill going at $12 \mathrm{~m} / \mathrm{min}$ for 15-30 min and then evaluated for $\mathrm{EBD}^{+}$myofibers in each muscle group of the legs. (a) The percentages of EBD ${ }^{+}$myofibers in the control leg muscles were arbitrarily set at $100 \%$ to determine the relative percentages of EBD ${ }^{+}$myofibers in the contralateral Dys-injected leg muscles. The average normalized EBD levels are shown for each group of muscles. Two muscle pairs were omitted because staining was low (1\% or fewer $\mathrm{EBD}^{+}$myofibers). (b) Each data point represents the weighted average percentage of $\mathrm{EBD}^{+}$myofibers in one leg. Statistical analysis comparing contralateral pairs of muscles was performed with a two-tailed, Wilcoxon signed rank test $(* * p<0.01)$.

Fig. 6, dystrophin-expressing myofibers excluded EBD. Dystrophin expression was not evident in either the myofibers that were darkly stained with EBD or in those that stained only lightly (Fig. 6a and b). The darkly stained EBD ${ }^{+}$ myofibers were clearly damaged, as can be seen by histological staining. Serum proteins including $\operatorname{IgG}$ antibodies leaked into these myofibers. These endogenous IgG antibodies were detected by immunohistochemistry with an FITC-conjugated anti-mouse IgG secondary antibody. EBDalbumin also leaked into the damaged myofibers. Autofluorescing EBD appears red. Overlapping FITC and EBD signals appear yellow-green in the myofibers that stained darkly for EBD. The secondary antibody also labeled the antidystrophin mouse polyclonal antibodies, seen as staining around the periphery of the myofibers. Lightly EBD-stained myofibers, although leaky, appeared to be morphologically more normal (Fig. 6b). We characterized dark and light EBD staining in $m d x$ mice and found that darkly stained myofibers increased after a vigorous exercise regimen, but not the approximately $1 \%$ of myofibers that stained lightly with EBD (Wooddell et al., 2009).

EBD staining is highly variable between animals and even in the anatomical location within the legs of individual $m d x$ mice (McGeachie et al., 1993; Straub et al., 1997; Wooddell et al., 2009). In subsequent short-term and long-term gene therapy studies, therefore, we used one hind leg as an internal control for the dystrophin plasmid therapeutic treatment given to the other leg (Table 1, studies 6, 10, and 11). The $m d x$ mice in these experiments were injected six times in one leg with CMV-HMGi-mDys or CMV-SV40i-mDys.

The first of the EBD studies that used one leg as an internal control for dystrophin pDNA injections in the other was a relatively short-term evaluation in which young adult $m d x$ $10 \mathrm{ScSn}$ mice received six HLV injections of CMV-HMGimDys in the left leg, 2 weeks between injections (Table 1, study 10). Three to 4 months after the first gene transfer, the mice were exercised on a rotarod, injected with EBD, and killed to quantitate dystrophin expression and the percentages of EBD-stained myofibers in muscles throughout both legs. The average percentage of dystrophin-expressing myofibers in muscle groups $2-4$ was $12.4 \pm 1.6 \%$ and the average dystrophin protein expression in these muscles was $20 \pm 3 \%$. Dystrophin expression in each group of muscles is shown in Supplementary Fig. 3a and b at www.liebertonline.com/hum. As expected for this strain, the control legs had an average of $0.6 \%$ revertant myofibers.

The rotarod exercise regimen was effective for challenging only some of the muscles of the mice in this short-term study, at least in part because the mice exercised inconsistently and their serum CK levels increased on average only 5-fold. The degree of protection that is possible depends not only on the reduction in EBD staining of the Dys-injected leg, but also on sufficient levels of EBD staining in the control samples. When the number of $\mathrm{EBD}^{+}$myofibers in the control leg is low, such as when the muscles are not sufficiently challenged by the exercise regimen, it is difficult to detect any potential protective effect from dystrophin expression in the other leg. Microscopy images of the posterior thigh muscles from both legs of one of the mice that exercised well show that dystrophin-expressing myofibers excluded EBD, and EBD staining throughout this group of muscles was reduced by $71 \%$ in the Dys-injected leg, compared with the same group of muscles in the contralateral control leg (Fig. 6c and data not shown). The whole Dys-injected limbs in this group of mice had on average $50 \%$ fewer $\mathrm{EBD}^{+}$myofibers than their contralateral control legs (data not shown).

The second study using an internal control leg was a longterm study. Young adult $m d x 4 \mathrm{Cv}$ mice were given six HLV injections of CMV-HMGi-mDys over a 5-month period and the doses were adjusted for the increasing weight of the animals (Fig. 7; Table 1, study 6). The $491-\mu \mathrm{g} / \mathrm{ml}$ dose was equal to $2 \times 10^{13}$ plasmids/ml for CMV-HMGi-mDys and $2 \times 10^{14}$ plasmids $/ \mathrm{ml}$ for the smaller control plasmid. The mice in this long-term study were evaluated when they were 
14-15 months old, which was 10 months after the first gene delivery and 5 months after the last. Mice were exercised on a treadmill, resulting in a $48 \pm 8$-fold increase in serum CK levels that confirmed muscles had been challenged in all animals. The Dys-injected legs had levels of dystrophin expression similar to those in the short-term study, an average of $12.9 \pm 1.5 \%$ dystrophin-expressing myofibers and $18 \pm 2 \%$ dystrophin protein in muscle groups $2-4$ (see Supplementary Fig. 3c and d for dystrophin expression data). The control legs had an average of $0.06 \%$ revertant myofibers.

For each animal and each group of muscles, the percentages of $\mathrm{EBD}^{+}$myofibers in the Dys-injected legs were compared with their contralateral control muscles (Fig. 7). Compared with their controls, the Dys-injected legs had 4.9fold fewer damaged (dark $\mathrm{EBD}^{+}$) myofibers in the medial thigh muscles, 4.0-fold fewer in the posterior lower leg, and 2.5-fold fewer in the posterior thigh (Fig. 7a). The two groups of anterior leg muscles that were transfected least well showed no significant improvement. In the whole Dysinjected limbs, all groups of muscle included, there were an average of 2.5-fold fewer $\mathrm{EBD}^{+}$myofibers than in the control legs, a 58\% reduction in the Dys-injected compared with the control legs (Fig. 7b).

A third independent long-term study using an internal control leg confirmed that the reduction in EBD staining depended on the level of dystrophin expression (Table 1, study 11). A group of $m d x$ mice was injected six times in one leg with a suboptimal dose of CMV-SV40i-mDys, which expresses less dystrophin than CMV-HMGi-mDys. In addition, this pDNA preparation caused some batch-dependent muscle toxicity. The injections were performed over a period of 5 months and the mice were evaluated 5 months after the last gene transfer. Only $4.4 \%$ of the myofibers in muscle groups 2-4 expressed dystrophin, and these muscles contained $5 \%$ of the normal amount of dystrophin protein (data not shown). Although this amount of dystrophin expression protected myofibers less than in the previous studies, there was a $46 \%$ reduction in $\mathrm{EBD}^{+}$myofibers in the dystrophin pDNA-injected legs compared with their contralateral controls $(p=0.016)$.

In summary, four independent studies indicated that pDNA encoding the full-length dystrophin gene delivered by HLV injections protected leg muscles from exerciseinduced muscle damage. The protection was as high as nearly 5-fold in muscles that expressed the most dystrophin, an average of $16 \%$ dystrophin-positive myofibers and an average of $20 \%$ of the wild-type amount of dystrophin protein. Muscles that had as few as 4\% dystrophin-expressing myofibers were afforded some protection, but much less than in the muscles with higher expression.

\section{Discussion}

Studies with transgenic $m d x$ mice show substantial reduction in the dystrophic pathology of mice expressing $20 \%$ of the normal level of full-length dystrophin (Phelps et al., 1995; Wells et al., 1995). Although not fully reversing the dystrophic phenotype, lower levels of expression also reduced the dystrophic pathology. Partial improvement in the dystrophic phenotype due to low levels of dystrophin expression was validated in the $m d x 3 \mathrm{Cv}$ mouse strain, which produces approximately $5 \%$ of the normal level of almost full-length dystrophin ( $\mathrm{Li}$ et al., 2008). In this case the mice produce a uniform low level of expression. They showed improved muscle strength, compared with the $m d x 4 \mathrm{Cv}$ strain, but similar muscle pathology such as central nuclei, variable myofiber size, macrophage infiltration, and sarcolemmal damage, the latter being measured by EBD uptake. Thus, protection of the myofibers from exercise-induced damage appears to require more than $5 \%$ dystrophin per myofiber.

Viral vectors encoding mini- or microdystrophin genes are under consideration for the treatment of muscular dystrophy (Rodino-Klapac et al., 2007), but pDNA therapy has the advantage of being amenable to repeated treatments that provide additive amounts of dystrophin expression. The ability to perform repeated gene deliveries seems especially important for a chronic disease. It may also be a consideration that while truncated forms of dystrophin improve function in $m d x$ mice, they may restore only partial function in humans. Adeno-associated viral vectors have the capacity for truncated forms of the dystrophin gene, but not the full-length gene. Full-length dystrophin protein alleviates dystrophic symptoms at a lower dose than is needed for alleviation of symptoms by minidystrophin expression. Another advantage of naked pDNA is that it is easily produced and relatively inexpensive, whereas large-scale production of viral vectors is much more challenging and costly.

Although $m d x$ mice have been reported to generate humoral and cytotoxic immune responses to human dystrophin expressed from intramuscularly injected pDNA (Braun et al., 2000), we and others have not noted any cytotoxic response to the expression of full-length mouse dystrophin (Ferrer et al., 2000; Zhang et al., 2004). We previously observed an antibody response in most $m d x$ mice injected with full-length mouse dystrophin plasmid, whether expressed from the viral CMV promoter or the muscle-specific desmin promoter (Zhang et al., 2004). Such a response was not previously observed after intramuscular injection of a much smaller dose of mouse dystrophin pDNA (Ferrer et al., 2000). Even though anti-dystrophin antibodies were produced after whole limb hydrodynamic injection, we show in this study that dystrophin was stably expressed for the lifetime of the mouse. Any immune response that occurred in the mice did not prevent long-term expression of dystrophin at the doses that were used.

The full-length dystrophin gene was delivered by intramuscular injection into DMD and Becker patients in a phase 1 trial and was shown to have an excellent safety profile with no adverse effects (Romero et al., 2004). The plasmid TG5001 used in that trial was the human equivalent of the CMVHMGi-mDys that gave substantial protection from myofiber damage to $m d x$ mice in our studies. Intramuscular delivery provided only modest dystrophin expression. Our studies suggest that dystrophin expression could be substantially increased by HLV delivery of the dystrophin-expressing pDNA.

Hydrodynamic limb vein injection is a robust procedure for delivering a therapeutic gene to the skeletal muscles of the limbs. In primates the delivery procedure requires no surgery, as injections are transcutaneous, and in rodents only minor surgery is required to access a surface vein. Gene delivery was as efficient in dystrophic mice as in wild-type mice, and as effective in aged mice as in young ones, as long 
as the dose of pDNA was adjusted for the increased leg mass of the older animals. The HLV gene delivery procedure is tolerated well by the dystrophic mice and repeat injections can be performed over an extended period of time to increase the number of expressing myofibers, as well as the overall amount of gene product.

Large plasmids like those expressing the full-length dystrophin gene transfect myofibers less efficiently than smaller plasmids delivered by HLV injection (Zhang et al., 2004). In wild-type C57BL/ 6 mice, an average of $24-27 \%$ of myofibers in the three large groups of hind leg muscles expressed $\beta$-galactosidase after just one HLV injection of $100 \mu \mathrm{g}$ of CMV-LacZ (data not shown). A similar experiment in rats showed that up to $40 \%$ of the myofibers in some large muscle groups were transfected by a single HLV injection (Hagstrom et al., 2004; and our unpublished data). A single HLV injection of an optimal dose of the large dystrophin plasmids transfected $4-8 \%$ of the myofibers throughout the injected limb, and multiple injections increased the amount of expression. HLV injection results in a fairly even distribution of dystrophin-expressing myofibers scattered throughout most muscles and high levels of expression in the myofibers that are visibly transfected. Dystrophin protein levels increased additively with multiple injections. The percentages of transfected myofibers increased with multiple injections in a manner that suggested at least some of the myofibers transfected by the initial injection were also transfected by subsequent injections.

Our previous study demonstrated that full-length dystrophin expressed from pDNA prevents myofiber turnover (Danko et al., 1993). In the current study, dystrophin expression from the CMV-driven dystrophin plasmid containing the HMG1 intron was stable for the life of the mice and provided significant benefit to the limbs. An improvement in muscle strength was measured by whole body tension, also called the escape test, in $m d x$ mice that received the dystrophin-expressing pDNA. Using Evans blue dye, we then analyzed in detail the protective effect of dystrophin plasmid delivery throughout the hind legs. Large groups of muscles in the dystrophin plasmid-injected legs had 4- to 5 -fold less damaged muscle than the contralateral muscles of the control legs, and whereas the vast majority of muscles in the control legs clearly had damaged muscles, most of the muscles in the dystrophin plasmid-injected legs had only low amounts of myofiber damage. This amount of protection resulted from dystrophin expression in just $11-16 \%$ of the myofibers. Significant muscle protection from less than $20 \%$ dystrophin-expressing myofibers suggests that there is a strong bystander effect. Myofibers that were transfected appear to have taken in sufficient pDNA to express physiological amounts of dystrophin, and these dystrophin-positive myofibers were distributed fairly evenly throughout a group of leg muscles. It appears that the high-expressing myofibers may serve as flexible anchors, so to speak, stabilizing much of the muscle.

The degree of protection measured in young adult mice evaluated soon after the last gene delivery was similar to that in aged mice injected over an extended period of time and evaluated when they were old. A significant protective effect could be measured in more areas of the legs of older mice compared with the younger ones in the short-term study, but this was likely due to the more consistent exercise regimen of treadmill running and the higher biological consistency between contralateral groups of muscles in old mice (Wooddell et al., 2009).

The amount of dystrophin expressed in aged mice appeared to be higher than that expressed in younger animals. Given that $m d x$ mice have a decreased ability to regenerate muscle as they age, the higher dystrophin expression in old mice suggests that the myofibers that expressed dystrophin may have had a selective advantage. This phenomenon resembles the selective pressure that results in genetic normalization of dystrophin expression in DMD carriers with skewed X-inactivation (Pegoraro et al., 1995). In essence, the dystrophin-negative myofibers are lost by necrosis, resulting in a higher proportion of muscle that is positive for dystrophin expression.

There is some debate as to whether stable, long-term expression of pDNA in mammalian cells requires removal of bacterial sequences and $\mathrm{CpG}$ dinucleotides from the plasmid vector (McMahon et al., 1998; Wells et al., 1998; Darquet et al., 1999) or if a scaffold/matrix attachment region (S/MAR) and tissue-specific promoter are required to prevent transgene silencing (Argyros et al., 2008). We and others have demonstrated high and stable levels of long-term expression in the liver (Miao et al., 2000; Wooddell et al., 2005, 2008) and in muscle (Sebestyen et al., 2007) from plasmids containing a bacterial backbone including the ColE1 origin of replication and devoid of any S/MAR element. A tissue-specific promoter and enhancer/locus control element were key in some of these studies, but were not necessarily required (Yew et al., 2001). In most of these reports the intron contributed greatly to the level of expression and its stability, as the HMG1 intron appears to do in the dystrophin expression plasmid. Although the CMV-HMGi-mDys plasmid construct does contain a bacterial plasmid backbone, it is also composed of approximately 15.5 kilobase pairs from the dystrophin gene that have a low $\mathrm{CpG}$ dinucleotide content. We cannot rule out the possibility that the low CpG content contributed to the stability of expression, or that expression could be increased by removal of $\mathrm{CpG}$ motifs in the vector backbone.

An inflammatory response or muscle damage has been reported as being associated with pDNA delivery to muscle by either intramuscular injection or electroporation (McMahon et al., 1998; Wells et al., 1998; Hartikka et al., 2001; Durieux et al., 2004), and in some cases was attributed to unmethylated CpG motifs in the bacterially derived pDNA. We, too, have observed damaged muscle in wild-type rodents within a few days of pDNA delivery. However, this response was completely dependent on the pDNA preparation, not the sequence of the pDNA. Some pDNA preparations caused significant amounts of muscle damage, whereas other preparations of the same plasmids caused no detectable damage at even large doses (C.I. Wooddell, V. Subbotin, M. Sebestyen, G. Zhang, J.B. Griffin, T. Huss, and J.A. Wolff, unpublished data). Although further studies are needed to determine the toxic contaminant in some pDNA batches, preparations can be produced without this component.

Translation of full-length dystrophin gene therapy from mice to humans would likely benefit by improvements to the vector. The CMV promoter provides long-term expression in mice, but plasmid expression in primate muscle was more stable when the muscle creatine kinase promoter was used (Sebestyen et al., 2007). A muscle-specific promoter is also 
expected to be safer because it is less likely to express the transgene in antigen-presenting cells. The large HMG intron was more effective for expression than the small SV40 intron, but the larger plasmid size makes its delivery less efficient. Large introns can be internally deleted to reduce the size while maintaining the beneficial effects for expression (Miao et al., 2000; Wooddell et al., 2008). The size of the vector and the bacterial sequences could be reduced further by using a minicircle construct (Darquet et al., 1999; Chen et al., 2005). These changes are expected to improve the efficiency of pDNA delivery and expression in mammalian muscles, allowing for fewer injections to obtain the desired level of dystrophin expression.

In conclusion, our studies demonstrate improvement in muscle function after HLV-mediated dystrophin plasmid delivery in the $m d x$ mouse model and provide support for the use of this approach in human clinical trials.

\section{Acknowledgments}

The authors thank Ying-hua Bian and Jessica Connor (University of Wisconsin-Madison) and Tracie Milarch, Mark Noble, and Mavis Eldridge (Roche Madison) for technical assistance with animals, Vladimir Subbotin for histological evaluations, Magdolna Sebestyén for critical discussions regarding plasmid DNA quality evaluation, and James Ludtke for assistance with images (all from Roche Madison); Tom Delahanty (IITC) for customization of the treadmill; and Jens Eickhoff and Michael Evans (University of WisconsinMadison) for statistical analysis. Funding was provided by the Association Française contre les Myopathies.

\section{Author Disclosure Statement}

G. Zhang, C.I. Wooddell, J.O. Hegge, J.B. Griffin, and J.A. Wolff are employed by Roche Madison, which owns patents for the hydrodynamic limb vein delivery procedure. T. Huss is employed by Transgene, which conducted a phase I clinical trial for MyoDys plasmid delivery by intramuscular injection.

\section{References}

Acsadi, G., Dickson, G., Love, D.R., Jani, A., Walsh, F.S., Gurusinghe, A., Wolff, J.A., and Davies, K.E. (1991). Human dystrophin expression in $m d x$ mice after intramuscular injection of DNA constructs. Nature 352, 815-818.

Allamand, V., and Campbell, K.P. (2000). Animal models for muscular dystrophy: Valuable tools for the development of therapies. Hum. Mol. Genet. 9, 2459-2467.

Argyros, O., Wong, S.P., Niceta, M., Waddington, S.N., Howe, S.J., Coutelle, C., Miller, A.D., and Harbottle, R.P. (2008). Persistent episomal transgene expression in liver following delivery of a scaffold/matrix attachment region containing non-viral vector. Gene Ther. 15, 1593-1605.

Blake, D.J., Weir, A., Newey, S.E., and Davies, K.E. (2002). Function and genetics of dystrophin and dystrophin-related proteins in muscle. Physiol. Rev. 82, 291-329.

Braun, S. (2008). Muscular gene transfer using nonviral vectors. Curr. Gene Ther. 8, 391-405.

Braun, S., Thioudellet, C., Rodriguez, P., Ali-Hadji, D., Perraud, F., Accart, N., Balloul, J.M., Halluard, C., Acres, B., Cavallini, B., and Pavirani, A. (2000). Immune rejection of human dystrophin following intramuscular injections of naked DNA in $m d x$ mice. Gene Ther. 7, 1447-1457.
Brussee, V., Tardif, F., and Tremblay, J.P. (1997). Muscle fibers of $m d x$ mice are more vulnerable to exercise than those of normal mice. Neuromuscul. Disord. 7, 487-492.

Bulfield, G., Siller, W.G., Wight, P.A., and Moore, K.J. (1984). $\mathrm{X}$ chromosome-linked muscular dystrophy $(m d x)$ in the mouse. Proc. Natl. Acad. Sci. U. S. A. 81, 1189-1192.

Burdi, R., Didonna, M.P., Pignol, B., Nico, B., Mangieri, D., Rolland, J.F., Camerino, C., Zallone, A., Ferro, P., Andreetta, F., Confalonieri, P., and De Luca, A. (2006). First evaluation of the potential effectiveness in muscular dystrophy of a novel chimeric compound, BN 82270, acting as calpain-inhibitor and anti-oxidant. Neuromuscul. Disord. 16, 237-248.

Chen, Z.Y., He, C.Y., and Kay, M.A. (2005). Improved production and purification of minicircle DNA vector free of plasmid bacterial sequences and capable of persistent transgene expression in vivo. Hum. Gene Ther. 16, 126-131.

Cossu, G., and Sampaolesi, M. (2007). New therapies for Duchenne muscular dystrophy: Challenges, prospects and clinical trials. Trends Mol. Med. 13, 520-526.

Coulton, G.R., Morgan, J.E., Partridge, T.A., and Sloper, J.C. (1988). The $m d x$ mouse skeletal muscle myopathy. I. A histological, morphometric and biochemical investigation. Neuropathol. Appl. Neurobiol. 14, 53-70.

Danko, I., Chapman, V., and Wolff, J.A. (1992). The frequency of revertants in $m d x$ mouse genetic models for Duchenne muscular dystrophy. Pediatr. Res. 32, 128-131.

Danko, I., Fritz, J.D., Latendresse, J.S., Herweijer, H., Schultz, E., and Wolff, J.A. (1993). Dystrophin expression improves myofiber survival in $m d x$ muscle following intramuscular plasmid DNA injection. Hum. Mol. Genet. 2, 2055-2061.

Danko, I., Williams, P., Herweijer, H., Zhang, G., Latendresse, J.S., Bock, I., and Wolff, J.A. (1997). High expression of naked plasmid DNA in muscles of young rodents. Hum. Mol. Genet. 6, 1435-1443.

Darquet, A.M., Rangara, R., Kreiss, P., Schwartz, B., Naimi, S., Delaere, P., Crouzet, J., and Scherman, D. (1999). Minicircle: An improved DNA molecule for in vitro and in vivo gene transfer. Gene Ther. 6, 209-218.

Deconinck, N., and Dan, B. (2007). Pathophysiology of Duchenne muscular dystrophy: Current hypotheses. Pediatr. Neurol. 36, 1-7.

De la Porte, S., Morin, S., and Koenig, J. (1999). Characteristics of skeletal muscle in $m d x$ mutant mice. Int. Rev. Cytol. 191, 99-148. Dellorusso, C., Crawford, R.W., Chamberlain, J.S., and Brooks, S.V. (2001). Tibialis anterior muscles in $m d x$ mice are highly susceptible to contraction-induced injury. J. Muscle Res. Cell Motil. 22, 467-475.

De Luca, A., Pierno, S., Liantonio, A., Cetrone, M., Camerino, C., Fraysse, B., Mirabella, M., Servidei, S., Ruegg, U.T., and Conte Camerino, D. (2003). Enhanced dystrophic progression in $m d x$ mice by exercise and beneficial effects of taurine and insulinlike growth factor-1. J. Pharmacol. Exper. Ther. 304, 453-463. Den Dunnen, J.T., Grootscholten, P.M., Bakker, E., Blonden, L.A., Ginjaar, H.B., Wapenaar, M.C., Van Paassen, H.M., Van Broeckhoven, C., Pearson, P.L., and Van Ommen, G.J. (1989). Topography of the Duchenne muscular dystrophy (DMD) gene: FIGE and cDNA analysis of 194 cases reveals 115 deletions and 13 duplications. Am. J. Hum. Genet. 45, 835-847.

Denti, M.A., Rosa, A., D'Antona, G., Sthandier, O., De Angelis, F.G., Nicoletti, C., Allocca, M., Pansarasa, O., Parente, V., Musaro, A., Auricchio, A., Bottinelli, R., and Bozzoni, I. (2006). Body-wide gene therapy of Duchenne muscular dystrophy in the $m d x$ mouse model. Proc. Natl. Acad. Sci. U. S. A. 103, 3758-3763. 
Duan, D. (2008). Myodys, a full-length dystrophin plasmid vector for Duchenne and Becker muscular dystrophy gene therapy. Curr. Opin. Mol. Ther. 10, 86-94.

Durieux, A.C., Bonnefoy, R., Busso, T., and Freyssenet, D. (2004). In vivo gene electrotransfer into skeletal muscle: Effects of plasmid DNA on the occurrence and extent of muscle damage. J. Gene Med. 6, 809-816.

Ervasti, J.M., and Campbell, K.P. (1991). Membrane organization of the dystrophin-glycoprotein complex. Cell 66, 1121-1131.

Ferrer, A., Wells, K.E., and Wells, D.J. (2000). Immune responses to dystrophin: Implications for gene therapy of Duchenne muscular dystrophy. Gene Ther. 7, 1439-1446.

Goyenvalle, A., Vulin, A., Fougerousse, F., Leturcq, F., Kaplan, J.C., Garcia, L., and Danos, O. (2004). Rescue of dystrophic muscle through U7 snRNA-mediated exon skipping. Science 306, 1796-1799.

Grounds, M.D., Radley, H.G., Lynch, G.S., Nagaraju, K., and De Luca, A. (2008). Towards developing standard operating procedures for pre-clinical testing in the $m d x$ mouse model of Duchenne muscular dystrophy. Neurobiol. Dis. 31, 1-19.

Hagstrom, J.E., Hegge, J., Zhang, G., Noble, M., Budker, V., Lewis, D.L., Herweijer, H., and Wolff, J.A. (2004). A facile nonviral method for delivering genes and siRNAs to skeletal muscle of mammalian limbs. Mol. Ther. 10, 386-398.

Hartikka, J., Sukhu, L., Buchner, C., Hazard, D., Bozoukova, V., Margalith, M., Nishioka, W.K., Wheeler, C.J., Manthorp, M., and Sawdey, M. (2001). Electroporation-facilitated delivery of plasmid DNA in skeletal muscle: Plasmid dependence of muscle damage and effect of poloxamer 188. Mol. Ther. 4, 407-415.

Hodgetts, S., Radley, H., Davies, M., and Grounds, M.D. (2006). Reduced necrosis of dystrophic muscle by depletion of host neutrophils, or blocking TNF $\alpha$ function with Etanercept in $m d x$ mice. Neuromuscul. Disord. 16, 591-602.

Jiao, S., Williams, P., Berg, R.K., Hodgeman, B.A., Liu, L., Repetto, G., and Wolff, J.A. (1992). Direct gene transfer into nonhuman primate myofibers in vivo. Hum. Gene Ther. 3, 21-33.

Kimura, E., Han, J.J., Li, S., Fall, B., Ra, J., Haraguchi, M., Tapscott, S.J., and Chamberlain, J.S. (2008). Cell-lineage regulated myogenesis for dystrophin replacement: A novel therapeutic approach for treatment of muscular dystrophy. Hum. Mol. Genet. 17, 2507-2517.

Koenig, M., Hoffman, E.P., Bertelson, C.J., Monaco, A.P., Feener, C., and Kunkel, L.M. (1987). Complete cloning of the Duchenne muscular dystrophy (DMD) cDNA and preliminary genomic organization of the DMD gene in normal and affected individuals. Cell 50, 509-517.

Le, T.P., Coonan, K.M., Hedstrom, R.C., Charoenvit, Y., Sedegah, M., Epstein, J.E., Kumar, S., Wang, R., Doolan, D.L., Maguire, J.D., Parker, S.E., Hobart, P., Norman, J., and Hoffman, S.L. (2000). Safety, tolerability and humoral immune responses after intramuscular administration of a malaria DNA vaccine to healthy adult volunteers. Vaccine 18, 18931901.

Lefaucheur, J.P., Pastoret, C., and Sebille, A. (1995). Phenotype of dystrophinopathy in old $m d x$ mice. Anat. Rec. 242, 70-76.

Li, D., Yue, Y., and Duan, D. (2008). Preservation of muscle force in $\mathrm{Mdx} 3 \mathrm{cv}$ mice correlates with low-level expression of a near full-length dystrophin protein. Am. J. Pathol. 172, 1332-1341.

Matsuda, R., Nishikawa, A., and Tanaka, H. (1995). Visualization of dystrophic muscle fibers in $m d x$ mouse by vital staining with Evans blue: Evidence of apoptosis in dystrophindeficient muscle. J. Biochem. 118, 959-964.
Matsumura, C.Y., Pertille, A., Albuquerque, T.C., Santo Neto, H., and Marques, M.J. (2009). Diltiazem and verapamil protect dystrophin-deficient muscle fibers of $M D X$ mice from degeneration: A potential role in calcium buffering and sarcolemmal stability. Muscle Nerve 39, 167-176.

Matsumura, K., Ohlendieck, K., Ionasescu, V.V., Tome, F.M., Nonaka, I., Burghes, A.H., Mora, M., Kaplan, J.C., Fardeau, M., and Campbell, K.P. (1993). The role of the dystrophinglycoprotein complex in the molecular pathogenesis of muscular dystrophies. Neuromuscul. Disord. 3, 533-535.

McGeachie, J.K., Grounds, M.D., Partridge, T.A., and Morgan, J.E. (1993). Age-related changes in replication of myogenic cells in $m d x$ mice: Quantitative autoradiographic studies. J. Neurol. Sci. 119, 169-179.

McMahon, J.M., Wells, K.E., Bamfo, J.E., Cartwright, M.A., and Wells, D.J. (1998). Inflammatory responses following direct injection of plasmid DNA into skeletal muscle. Gene Ther. 5, 1283-1290.

Miao, C.H., Ohashi, K., Patijn, G.A., Meuse, L., Ye, X., Thompson, A.R., and Kay, M.A. (2000). Inclusion of the hepatic locus control region, an intron, and untranslated region increases and stabilizes hepatic factor IX gene expression in vivo but not in vitro. Mol. Ther. 1, 522-532.

Miura, P., and Jasmin, B.J. (2006). Utrophin upregulation for treating Duchenne or Becker muscular dystrophy: How close are we? Trends Mol. Med. 12, 122-129.

Monaco, A.P., Bertelson, C.J., Middlesworth, W., Colletti, C.A., Aldridge, J., Fischbeck, K.H., Bartlett, R., Pericak-Vance, M.A., Roses, A.D., and Kunkel, L.M. (1985). Detection of deletions spanning the Duchenne muscular dystrophy locus using a tightly linked DNA segment. Nature 316, 842-845.

Oblack, D.L., and Holder, I.A. (1979). Active immunisation of mice against muscle damage mediated by Candida albicans. J. Med. Microbiol. 12, 503-506.

Odom, G.L., Gregorevic, P., and Chamberlain, J.S. (2007). Viralmediated gene therapy for the muscular dystrophies: Successes, limitations and recent advances. Biochim. Biophys. Acta 1772, 243-262.

Okano, T., Yoshida, K., Nakamura, A., Sasazawa, F., Oide, T., Takeda, S., and Ikeda, S. (2005). Chronic exercise accelerates the degeneration-regeneration cycle and downregulates insulin-like growth factor- 1 in muscle of $m d x$ mice. Muscle Nerve 32, 191-199.

Pegoraro, E., Schimke, R.N., Garcia, C., Stern, H., Cadaldini, M., Angelini, C., Barbosa, E., Carroll, J., Marks, W.A., Neville, H.E., Marks, H., Appleton, S., Toriello, H., Wessel, H.B., Donnelly, J., Bernes, S.M., Taber, J.W., Weiss, L., and Hoffman, E.P. (1995). Genetic and biochemical normalization in female carriers of Duchenne muscular dystrophy: Evidence for failure of dystrophin production in dystrophin-competent myonuclei. Neurology 45, 677-690.

Petrof, B.J., Shrager, J.B., Stedman, H.H., Kelly, A.M., and Sweeney, H.L. (1993). Dystrophin protects the sarcolemma from stresses developed during muscle contraction. Proc. Natl. Acad. Sci. U. S. A. 90, 3710-3714.

Phelps, S.F., Hauser, M.A., Cole, N.M., Rafael, J.A., Hinkle, R.T., Faulkner, J.A., and Chamberlain, J.S. (1995). Expression of fulllength and truncated dystrophin mini-genes in transgenic $m d x$ mice. Hum. Mol. Genet. 4, 1251-1258.

Rodino-Klapac, L.R., Janssen, P.M., Montgomery, C.L., Coley, B.D., Chicoine, L.G., Clark, K.R., and Mendell, J.R. (2007). A translational approach for limb vascular delivery of the micro-dystrophin gene without high volume or high pressure for treatment of Duchenne muscular dystrophy. J. Transl. Med. 5, 45. 
Romero, N.B., Braun, S., Benveniste, O., Leturcq, F., Hogrel, J.Y., Morris, G.E., Barois, A., Eymard, B., Payan, C., Ortega, V., Boch, A.L., Lejean, L., Thioudellet, C., Mourot, B., Escot, C., Choquel, A., Recan, D., Kaplan, J.C., Dickson, G., Klatzmann, D., Molinier-Frenckel, V., Guillet, J.G., Squiban, P., Herson, S., and Fardeau, M. (2004). Phase I study of dystrophin plasmidbased gene therapy in Duchenne/Becker muscular dystrophy. Hum. Gene Ther. 15, 1065-1076.

Sampaolesi, M., Blot, S., D'Antona, G., Granger, N., Tonlorenzi, R., Innocenzi, A., Mognol, P., Thibaud, J.L., Galvez, B.G., Barthelemy, I., Perani, L., Mantero, S., Guttinger, M., Pansarasa, O., Rinaldi, C., Cusella de Angelis, M.G., Torrente, Y., Bordignon, C., Bottinelli, R., and Cossu, G. (2006). Mesoangioblast stem cells ameliorate muscle function in dystrophic dogs. Nature 444, 574-579.

Sebestyen, M.G., Hegge, J.O., Noble, M.A., Lewis, D.L., Herweijer, H., and Wolff, J.A. (2007). Progress toward a nonviral gene therapy protocol for the treatment of anemia. Hum. Gene Ther. 18, 269-285.

Straub, V., Rafael, J.A., Chamberlain, J.S., and Campbell, K.P. (1997). Animal models for muscular dystrophy show different patterns of sarcolemmal disruption. J. Cell Biol. 139, 375-385.

Toumi, H., Hegge, J., Subbotin, V., Noble, M., Herweijer, H., Best, T.M., and Hagstrom, J.E. (2006). Rapid intravascular injection into limb skeletal muscle: A damage assessment study. Mol. Ther. 13, 229-236.

Vandebrouck, C., Martin, D., Colson-Van Schoor, M., Debaix, H., and Gailly, P. (2002). Involvement of TRPC in the abnormal calcium influx observed in dystrophic $(m d x)$ mouse skeletal muscle fibers. J. Cell Biol. 158, 1089-1096.

Vigen, K.K., Hegge, J.O., Zhang, G., Mukherjee, R., Braun, S., Grist, T.M., and Wolff, J.A. (2007). Magnetic resonance imagingmonitored plasmid DNA delivery in primate limb muscle. Hum. Gene Ther. 18, 257-268.

Voisin, V., and De la Porte, S. (2004). Therapeutic strategies for Duchenne and Becker dystrophies. Int. Rev. Cytol. 240, 1-30.

Wells, D.J., Wells, K.E., Asante, E.A., Turner, G., Sunada, Y., Campbell, K.P., Walsh, F.S., and Dickson, G. (1995). Expression of human full-length and minidystrophin in transgenic $m d x$ mice: Implications for gene therapy of Duchenne muscular dystrophy. Hum. Mol. Genet. 4, 1245-1250.

Wells, D.J., Maule, J., McMahon, J., Mitchell, R., Damien, E., Poole, A., and Wells, K.E. (1998). Evaluation of plasmid DNA for in vivo gene therapy: Factors affecting the number of transfected fibers. J. Pharm. Sci. 87, 763-768.
Wolff, J.A., Ludtke, J.J., Acsadi, G., Williams, P., and Jani, A. (1992). Long-term persistence of plasmid DNA and foreign gene expression in mouse muscle. Hum. Mol. Genet. 1, 363369.

Wooddell, C.I., Van Hout, C.V., Reppen, T., Lewis, D.L., and Herweijer, H. (2005). Long-term RNA interference from optimized siRNA expression constructs in adult mice. Biochem. Biophys. Res. Commun. 334, 117-127.

Wooddell, C.I., Reppen, T., Wolff, J.A., and Herweijer, H. (2008). Sustained liver-specific transgene expression from the albumin promoter in mice following hydrodynamic plasmid DNA delivery. J. Gene Med. 10, 551-563.

Wooddell, C.I., Zhang, G., Griffin, J.B., Hegge, J.O., Huss, T., and Wolff, J.A. (2009). Use of Evans blue dye to compare limb muscles in exercised young and old $m d x$ mice. Muscle Nerve (in press).

Yew, N.S., Przybylska, M., Ziegler, R.J., Liu, D., and Cheng, S.H. (2001). High and sustained transgene expression in vivo from plasmid vectors containing a hybrid ubiquitin promoter. Mol. Ther. 4, 75-82.

Yokota, T., Pistilli, E., Duddy, W., and Nagaraju, K. (2007). Potential of oligonucleotide-mediated exon-skipping therapy for Duchenne muscular dystrophy. Expert Opin. Biol. Ther. 7, 831-842.

Zhang, G., Budker, V., Williams, P., Subbotin, V., and Wolff, J.A. (2001). Efficient expression of naked DNA delivered intraarterially to limb muscles of nonhuman primates. Hum. Gene Ther. 12, 427-438.

Zhang, G., Ludtke, J.J., Thioudellet, C., Kleinpeter, P., Antoniou, M., Herweijer, H., Braun, S., and Wolff, J.A. (2004). Intraarterial delivery of naked plasmid DNA expressing full-length mouse dystrophin in the $m d x$ mouse model of Duchenne muscular dystrophy. Hum. Gene Ther. 15, 770-782.

Address correspondence to: Dr. Christine Wooddell Roche Madison 465 Science Drive Madison, WI 53711

E-mail: chris.wooddell@roche.com

Received for publication July 23, 2009; accepted after revision September 25, 2009.

Published online: January 8, 2010. 